\title{
PRIVATE FOUNDATIONS' GIVING FOR DEVELOPMENT IN 2013-2015
}

Ongoing efforts to better reflect private philanthropic giving in OECD-DAC statistics on development finance

Julia Benn, Cécile Sangaré, Tomáš Hos

\section{OECD DEVELOPMENT CO-OPERATION WORKING PAPER 44}

Authorised for publication by Brenda Killen, Deputy Director, Development Co-operation Directorate 


\section{OECD Development Co-operation Working Papers}

OECD Working Papers should not be reported as representing the official views of the OECD or of its member countries. The opinions expressed and arguments employed are those of the authors.

Working Papers describe preliminary results or research in progress by the author(s) and are published to stimulate discussion on a broad range of issues on which the OECD works. Comments on the present Working Paper are welcomed and may be sent to Julia Benn (Julia.BENN@oecd.org) - the Development Co-operation Directorate, OECD, 2 rue André-Pascal, 75775 Paris Cedex 16, France.

This document and any map included herein are without prejudice to the status of or sovereignty over any territory, to the delimitation of international frontiers and boundaries and to the name of any territory, city or area.

You can copy, download or print OECD content for your own use, and you can include excerpts from OECD publications, databases and multimedia products in your own documents, presentations, blogs, websites and teaching materials, provided that suitable acknowledgement of OECD as source and copyright owner is given. All requests for public or commercial use and translation rights should be submitted to rights@oecd.org. 


\section{EXECUTIVE SUMMARY}

This working paper highlights the main results of the 2016-17 OECD data Survey on Global Private Philanthropy for Development and describes how this exercise relates to - and aims to complement - the existing regular data collection on development finance by the Development Co-operation Directorate (DCD).

The data survey aimed at better understanding who the main philanthropic actors active in development are. By aligning its scope and reporting format with ODA standards, the survey ensured that data collected from private philanthropic foundations were comparable, also with other development finance flows. Moreover, it also aimed to explore the extent to which such data were readily available in foundations' internal systems.

The survey gathered project-level data from 143 foundations all over the world. In general, the results and coverage of the survey were considered to be very good and showed that collecting comparable data from private philanthropic foundations was feasible.

The survey results reveal that private foundations gave USD 23.9 billion for development from 2013 to 2015. While the main beneficiary region was Africa (28\%), a large share of the foundations' activities had a multi-regional or unallocated scope. 53\% of foundations' total giving was provided for health and population policies/programmes \& reproductive health. $97 \%$ of the funds were channelled to/through implementing partners (the remaining $3 \%$ related to operational foundations' activities and scholarships/fellowships).

So far, only four philanthropic foundations report on a regular basis to the OECD according to the ODA standards: the Bill and Melinda Gates Foundation (BMGF) - since 2009 - and the United Postcode Lotteries (UPL, including the Dutch Postcode Lottery, Swedish Postcode Lottery and People's Postcode Lottery) - since 2017. The survey results suggest that more foundations could be in a position to start sharing their data with the OECD. In 2018, the OECD-DCD will pursue its statistical engagement with the largest philanthropic foundations, building on the BMGF and UPL's experiences. 


\section{TABLE OF CONTENTS}

EDITORIAL: WHY TRANSPARENCY OF PHILANTHROPIC FUNDING MATTERS? …………………………………..... 1

by Michael Jarvis, Executive Director of the Transparency \& Accountability Initiative

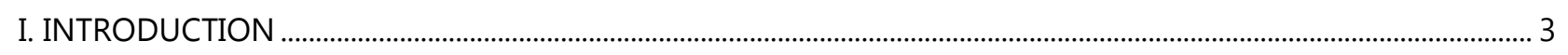

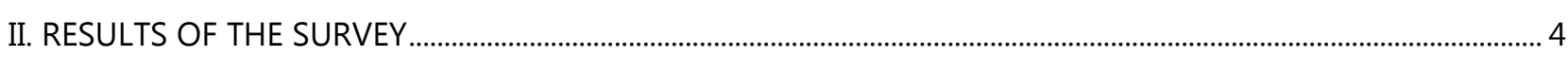

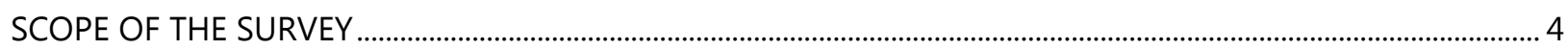

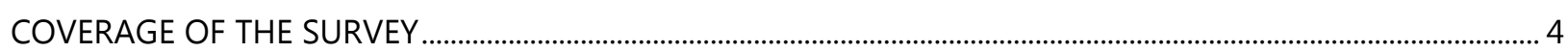

FOUNDATIONS' GIVING FOR DEVELOPMENT (ANALYSIS OF MAIN TRENDS) ………......................................... 5

III. OECD EFFORTS TO ENHANCE DAC STATISTICS ON PRIVATE PHILANTHROPY …….............................................14

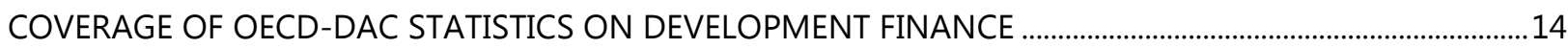

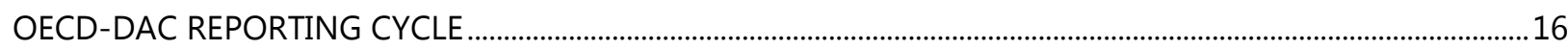

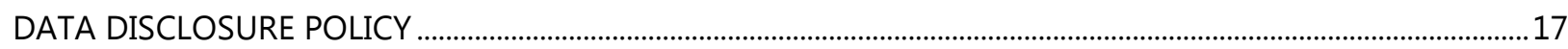

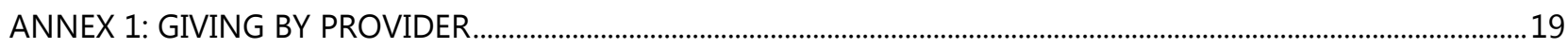

ANNEX 2: GIVING BY RECIPIENT AND MAIN SECTOR CATEGORY ..........................................................................23

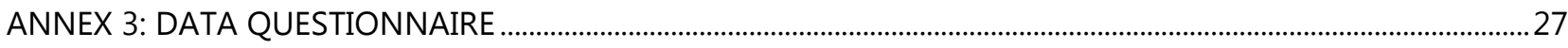

ANNEX 4: ESTIMATION OF FOUNDATIONS' CONTRIBUTION TO THE SDGS ..............................................................28

BOX 1: Giving by foundations based in developing countries.........................................................................

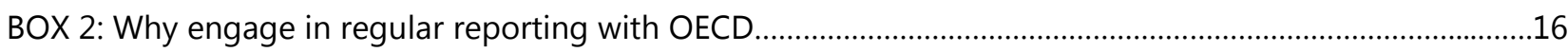

by Saara Romu, Senior Program Officer at Bill \& Melinda Gates Foundation

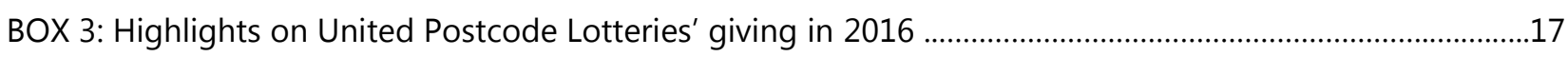




\section{ACKNOWLEDGEMENTS}

This working paper on Private Foundations' Giving for Development in 2013-15 was prepared by the Financing for Sustainable Development Division of the OECD Development Co-operation Directorate.

The authors would like to thank the contributors to this publication, namely Michael Jarvis (Transparency \& Accountability Initiative) and Saara Romu (the Bill and Melinda Gates Foundation), as well as all responding foundations for their considerable reporting efforts. Special thanks are also extended to Mohamed Awadelkarim Abdalla Ibrahim (UAE government) for facilitating the inclusion of the data on UAE-based philanthropies in the survey data sample, as well as Tracy Kang (康娟) from the China Charity Alliance and colleagues from the OECD Network of Foundations Working for Development (netFWD) for facilitating the data engagement process with some foundations.

The authors would also like to thank Jamie Attard, Swandi Chan and April McCoy (the Bill and Melinda Gates Foundation) for reviewing the data survey template during its preparation, as well as their continued statistical engagement with the OECD. 


\section{LIST OF ABBREVIATIONS}

\section{Institutional abbreviations}

$\begin{array}{ll}\text { BMGF } & \text { Bill and Melinda Gates Foundation } \\ \text { CIFF } & \text { Children's Investment Fund Foundation } \\ \text { DAC } & \text { Development Assistance Committee } \\ \text { DCD } & \text { Development Co-operation Directorate of the OECD } \\ \text { DPL } & \text { Dutch Postcode Lottery } \\ \text { Grameen CA } & \text { Grameen Crédit Agricole Foundation } \\ \text { HGBF } & \text { Howard G. Buffett Foundation } \\ \text { IATI } & \text { International Aid Transparency Initiative } \\ \text { IRS } & \text { Internal Revenue Service } \\ \text { NetFWD } & \text { Network of Foundations Working for Development } \\ \text { OECD } & \text { Organisation for Economic Co-operation and Development } \\ \text { OSF } & \text { Open Society Foundations } \\ \text { STBF } & \text { Susan T. Buffett Foundation } \\ \text { TAI } & \text { Transparency and Accountability Initiative } \\ \text { UAE RC } & \text { Red Crescent of the United Arab Emirates } \\ \text { UN } & \text { United Nations } \\ \text { UNHCR } & \text { United Nations High Commissioner for Refugees } \\ \text { UNICEF } & \text { United Nations Children's Fund } \\ \text { UPL } & \text { United Postcode Lotteries } \\ \text { WB } & \text { World Bank } \\ \text { WFHF } & \text { William and Flora Hewlett Foundation } \\ \text { WHO } & \text { World Health Organisation } \\ \text { WP-STAT } & \text { Working Party on Development Finance Statistics of the DAC } \\ \end{array}$

\section{Other abbreviations}

$\begin{array}{ll}\text { AAAA } & \text { Addis Ababa Action Agenda } \\ \text { CRS } & \text { Creditor Reporting System } \\ \text { CSO } & \text { Civil society organisation } \\ \text { DCR } & \text { Development Co-operation Report } \\ \text { FDI } & \text { Foreign direct investment } \\ \text { FGM } & \text { Forced genital mutilation } \\ \text { Fnd } & \text { Foundation } \\ \text { ODA } & \text { Official Development Assistance } \\ \text { LDC } & \text { Least developed country } \\ \text { LIC } & \text { Low-income country or territory } \\ \text { LMIC } & \text { Lower middle-income country or territory } \\ \text { MRI } & \text { Mission-related investments } \\ \text { NGO } & \text { Non-governmental organisation } \\ \text { OOF } & \text { Other Official Flows } \\ \text { PPP } & \text { Public-private partnership } \\ \text { PRI } & \text { Programme-related investments } \\ \text { Q } & \text { Quarter } \\ \text { RMNCH } & \text { Reproductive, Maternal, New-born and Child Health } \\ \text { SDG } & \text { Sustainable Development Goal } \\ \text { UMIC } & \text { Upper middle-income country or territory } \\ \text { UAE } & \text { United Arab Emirates } \\ \text { UK } & \text { United Kingdom } \\ \text { US } & \text { United States of America } \\ \text { USD } & \text { United States dollar } \\ & \end{array}$




\title{
EDITORIAL WHY TRANSPARENCY OF PHILANTHROPIC FUNDING MATTERS?
}

\author{
by Michael Jarvis, Executive Director of the Transparency \& Accountability Initiative (TAI)
}

The trend toward greater transparency of philanthropic funding is to be welcomed. Over 50 organisations in the United Kingdom publish to the open data 360Giving standard, over 90 foundations publish to Glass Pockets in the United States, and now this OECD survey brings together data from 143 foundations worldwide.

As funders of transparency efforts for good governance around the globe, the members of the Transparency and Accountability Initiative (TAI) - a donor collaborative of the Ford Foundation, Omidyar Network, Open Society Foundations and the William and Flora Hewlett Foundation together with MacArthur Foundation and the Department for International Development of the United Kingdom recognize the importance of being open about funding commitments. We expect government donors to be transparent on the use of public resources, and therefore also on the aid they provide, fostering accountability to the beneficiaries and to their home country tax payers. Although the accountability relationship is different for private donors, we believe that philanthropic funders also benefit from being open about grants made.

The benefits of greater data on philanthropic funding run deeper than satisfying public relations considerations. For one, we believe it important for building trust with grantees and beneficiaries, and assuring comfort with the role of philanthropy within society more broadly. As funders supporting international transparency, it is important for TAI members to "walk the talk", but we believe the credibility that transparency provides is beneficial to the philanthropic sector writ large. Of course, funders do need to be sensitive to individual privacy concerns and to protecting data that might create vulnerabilities for recipients in sensitive political contexts - a growing concern amid the proliferation of laws restricting civil society organisations in many countries, including legislation specifically limiting receipt of foreign funding.

As more funders publish information on grant making, it should lead to more effective future funding commitments. The data pool is useful for current and prospective grantees, but also a valuable resource for funders themselves. They can better benchmark their portfolios. By providing a bigger and more granular picture of where funds are flowing, publicly available grants data can help minimise duplication of efforts, and identify geographic and thematic gaps in funding. As more foundations make information available, the greater the utility - especially when combined with available information on official aid. Standard reporting templates such as OECD-DAC Creditor Reporting System (CRS) and the International Aid Transparency Initiative (IATI) can ease cross comparison. As Dan Sutch of Nominet has noted, "an individual grantmaking organisation might not alone make a huge difference in sharing their grants data, but when they are combined across multiple grantmaking organisations, then we might generate some real insight."

In a 2013 Institute for Philanthropy survey, donors reported that the greatest benefit of sharing more information about their giving was that it "facilitates collaboration." As a donor collaborative we have certainly found that to be true amongst our members. Indeed, the utility of grant data rises not just when combined with that of other funders, but when complemented by publication of contextual information. For example, grant makers can more proactively share their strategies as well as evaluations and evidence reviews. This helps to inform shared understanding not just of what gets funded, but why, and how funders adapt based on evidence of what is working or not.

Extending transparency on these fronts should further boost effectiveness of funding and stories of impact that may attract more funding for positive social change. It could become standard practice for new philanthropies. In that case, the OECD efforts to better capture private philanthropy worldwide - either through a next ad hoc survey or regular reporting to the OECD - could become a powerful tool for assuring donor transparency and accountability. 


\section{References}

360giving (2014), Foundation transparency: why it matters - article by Fran Perrin Alliance Magazine March 2014, www.threesixtygiving.org/2014/03/17/foundation-transparency-why-it-matters-article-by-fran-perrin-alliancemagazine-march-2014.

360giving (2018), Official website, www.threesixtygiving.org (accessed 26 February 2018).

Glass Pockets (2018), Official website, glasspockets.org (accessed 26 February 2018).

IATI (2018), Official website, www.aidtransparency.net (accessed 26 February 2018).

OECD (2018), Creditor Reporting System, stats.oecd.org/Index.aspx?DataSetCode=CRS1 (accessed 26 February 2018).

Rutzen, Douglas (2017), Threats to Civil Society Around the World, pp. 1.

The Philanthropy Workshop (2013), Towards Greater Transparency in Philanthropy, www.tpw.org/news/entry/towards_greater_transparency_in_philanthropy_full.

Transparency Initiative (2018), Official website, www.transparency-initiative.org (accessed 26 February 2018). 


\title{
I. INTRODUCTION
}

Over the past years, private philanthropic foundations have gained a solid place in the spectrum of financing for development. Embedding philanthropic efforts into the international development framework was first achieved in the Addis Agenda Action Agenda (AAAA), which drew the post-2015 development finance landscape:

\begin{abstract}
We [the Heads of State and Government and High Representatives] recognize philanthropic donors' flexibility and capacity for innovation and taking risks, and their ability to leverage additional funds through multi-stakeholder partnerships. (...) We welcome efforts to increase cooperation between philanthropic actors, Governments and other development stakeholders. We call for increased transparency and accountability in philanthropy. (...)
\end{abstract}

The 2030 Agenda, notably the SDG 17, also called for mobilising finance from all available sources, engaging in multi-stakeholder partnerships (including with private foundations), as well as improving transparency, accountability and statistics.

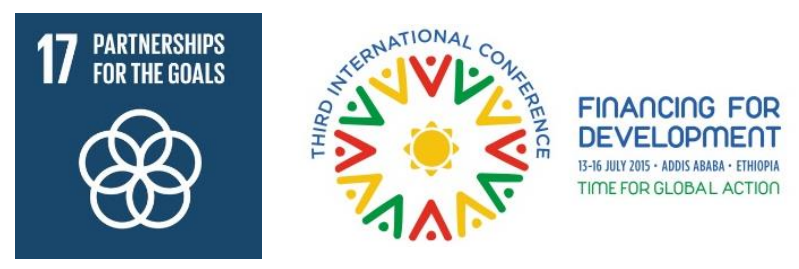

Analysing and optimising this growing phenomenon requires a comprehensive and evidence-based understanding of how foundations work. Even though the availability and quality of data on foundations' activities have recently been improving, datasets are often published in a multitude of formats, preventing comparison among foundations but also between foundations' giving and other development finance flows, such as Official Development Assistance (ODA).

To address the need of comparable data on philanthropy and to better understand the financing trends in this area, the OECD Development Co-operation Directorate (OECD-DCD) carried out in 2016-17 a large-scale Survey on Global Private Philanthropy for Development. This survey collected activity-level information on the charitable expenditures of philanthropic foundations all over the world, following the statistical standards used in the data collection on ODA.

The survey is also a cornerstone of the collaborative efforts between the OECD-DCD and the OECD Global Network of Foundations Working for Development (NetFWD) to update the 2003 OECD report on Philanthropic Foundations and Development Co-operation, the objective of which is to shed light on foundations' contributions to the 2030 Agenda more broadly.

The objectives of this working paper are to highlight the main findings of the survey (in section II) but also to describe how this exercise relates to the ongoing OECD-DCD efforts to improve its statistics on private philanthropic activities and development finance beyond ODA (in section III).

\section{References}

OECD (2003), "Philanthropic Foundations and Development Co-operation", DAC Journal 2003, Vol. 4/3,

www.oecd.org/development/stats/22272860.pdf.

OECD (2018), Private Philanthropy for Development, OECD Publishing, Paris, forthcoming.

UN (2015), Addis Ababa Action Agenda of the Third International Conference on Financing for Development, point 42, pp. 21.

www.un.org/esa/ffd/wp-content/uploads/2015/08/AAAA Outcome.pdf.

UN (2018), Sustainable Development Knowledge Platform, SDG 17, sustainabledevelopment.un.org/sdg17. 


\title{
II. RESULTS OF THE SURVEY
}

\section{SCOPE OF THE SURVEY}

For the purpose of the data survey, a working definition of private philanthropic flows for development was set out to ensure comparability of the data with the OECD-DAC statistics on ODA and to avoid double-counting at the international level:

\begin{abstract}
Private philanthropic flows for development refer to transactions from the private sector having the promotion of the economic development and welfare of developing countries as their main objective, and which originate from foundations' own sources, notably endowment, donations from companies and individuals (incl. high-net-worth individuals and crowdfunding), legacies, as well as income from royalties, investments (incl. government securities), dividends, lotteries and similar.
\end{abstract}

Following this definition, philanthropic activities funded by governments were out of scope.' Furthermore, charitable giving from religious institutions were only included if they aimed at supporting development and improving welfare.

Similar to the DAC statistical system tracking ODA flows, "developing countries" were defined according to the DAC List of ODA Recipients. In the case of core contributions to multilateral organisations, the DAC List of ODA-eligible international organisations was used to identify the extent to which such unrestricted support could be considered as contributing to development.

The DAC statistical system tracks external development finance. However, to acquire a better understanding of global philanthropic giving as a whole, the survey also collected data on foundations' activities in developing countries not necessarily constituting cross-border flows (e.g. philanthropic foundations operating domestically).

The survey had four main objectives. It aimed to

1. Fill a data gap by collecting internationally comparable data on private philanthropy for development in a format enabling comparability with other statistical standards, and ODA in particular;

2. Collect inputs and evidence for the forthcoming update of the 2003 OECD report on Private Foundations and Development Co-operation;

3. Test the feasibility of collecting comparable data on private philanthropy to ultimately improve the coverage of OECD statistics in this area;

4. Identify and start engaging with the largest philanthropic foundations active in development on regular reporting to the OECD.

\section{COVERAGE OF THE SURVEY}

Over 200 private philanthropic foundations identified as being active in development were invited to participate in the survey. The survey included two questionnaires:

- A data questionnaire (see Annex 3) on foundations' activities extended with development as their main objective from 2013 to 2015 . This questionnaire aimed at collecting activity-level, both quantitative and descriptive information (such as the geographical and sectoral distributions, the channels of delivery, the modalities of giving and other qualitative information). 
- A qualitative questionnaire (developed by the OECD netFWD), comprised of multiple-choice and rating questions on the type of funding provided, transparency \& accountability, as well as on co-operation modalities with governments and other development partners. ${ }^{i i}$

Overall, the survey gathered information on 147 foundations:

- 77 foundations responded to both the data and qualitative questionnaires. The survey data for the Bill and Melinda Gates Foundation and 12 UAE-based foundations were derived from their regular reporting on private grants to the OECD-DAC.

- For 53 foundations, activity-level data were collected from publicly available sources, particularly the US Internal Revenue Service (IRS) Form 990-PFiii (31), foundations' own websites (14) and annual reports (7) or through datasets available through the International Aid Transparency Initiative (IATI; 2).

- Four foundations completed the qualitative questionnaire only due to capacity constraints or confidentiality concerns.

The data were collected under a strict confidentiality agreement with the data providers, implying that information on individual activities cannot be shared nor disclosed. It was agreed that the data may be presented exclusively at the aggregate level. BMGF's activities reported to the OECD on a regular basis are however fully disclosed online at OECD.Stat.

\section{FOUNDATIONS' GIVING FOR DEVELOPMENT}

\section{Foundations gave USD 23.9 billion for development in 2013-15}

Based on the survey results, private philanthropic foundations provided USD 23.9 billion for development in 2013-15, or USD 7.96 billion per year on average. Philanthropic giving over this period followed an upward trend with an annual increase of $19 \%$ on average, mainly driven by European foundations and the Bill and Melinda Gates Foundation. Indeed, European foundations' giving in 2015 was 53\% higher than in 2013.

\section{Figure 1. Foundations' giving over 2013-15, USD billion}

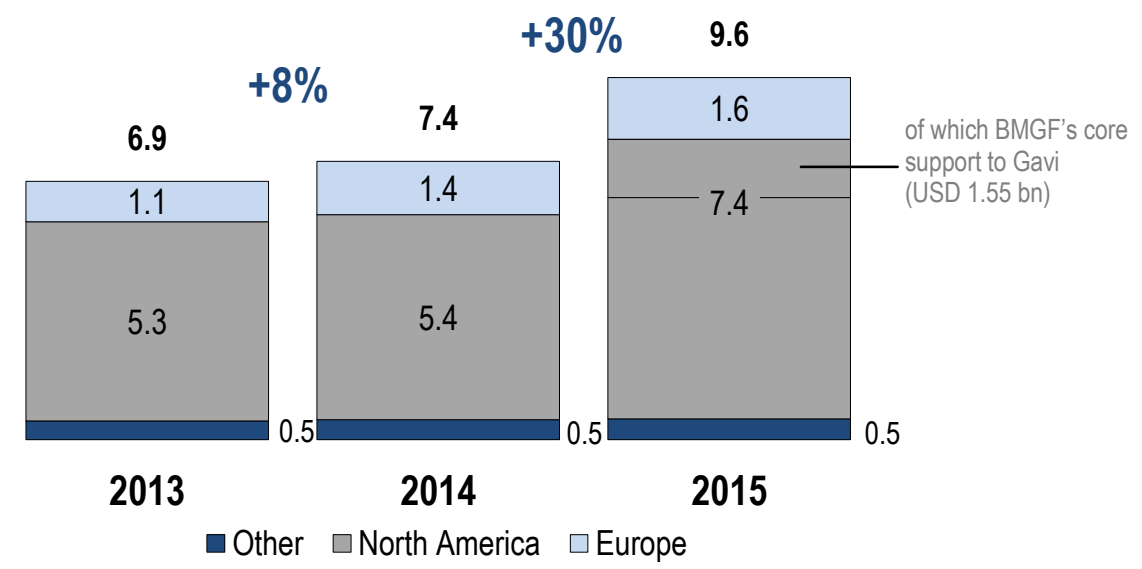

Over $99 \%$ of the three-year total was provided in the form of grants ${ }^{\mathrm{iv}}$ (incl. direct giving and activities under foundations' execution). Other non-grant financial instruments used for charitable activities ${ }^{v}$ were standard loans (incl. bonds and mortgages; $0.4 \%$ ), equity investments (0.2\%) and shares in collective investment vehicles $(0.1 \%)$. A few foundations also provided guarantees with a total exposure of up to USD 37.6 million. 
BMGF is by far the largest foundation, but other foundations played an important role too With over USD 11.6 billion of giving over 2013-15, the Bill and Melinda Gates Foundation (BMGF) was by far the most generous foundation in the world (49\% of the total), followed by Children's Investment Fund Foundation (CIFF), Susan Thompson Buffett Foundation (STBF), Dutch Postcode Lottery (DPL) and Ford Foundation (3\% each). Philanthropic giving was rather concentrated, with the top 20 private foundations' giving representing $81 \%$ of the total.

Figure 2. Main foundations active in development, USD million, 2013-15

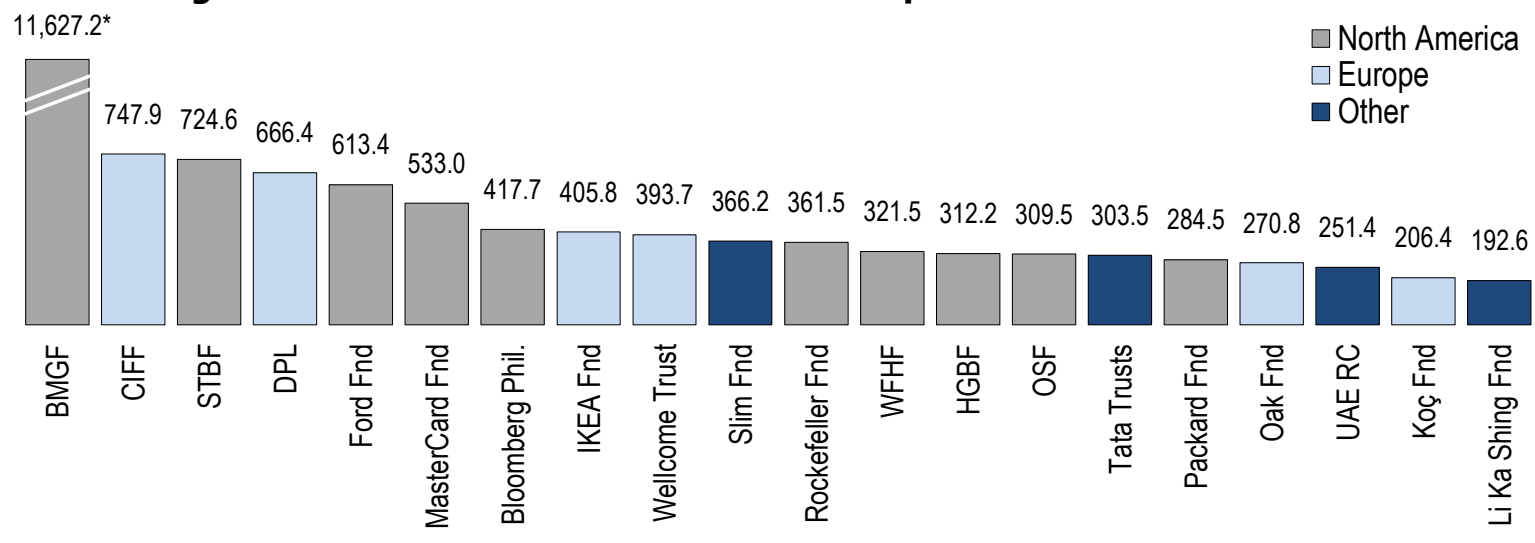

*The column size for the BMGF was reduced for illustrative purposes

Even though North-American foundations accounted for three-quarters (76\%) of total giving, four of the top 10 foundations were Europe-based. Of the remaining 24\%, Europe-based foundations accounted for $17 \%$ and foundations based elsewhere $7 \%{ }^{\text {vi }}$

\section{Health \& reproductive health ${ }^{\text {vii }}$ were the main sectors targeted}

As shown in figure 3, foundations' giving predominantly targeted the health \& reproductive health sectors, which together accounted for $53 \%$ of the total. Even though $72 \%$ of total giving for health \& reproductive health related to BMGF's activities, this sector category was the main funding priority for many other foundations too, in particular the Susan T. Buffett Foundation (STBF; 5\%), Children's Investment Fund Foundation (CIFF; 4\%), Wellcome Trust (3\%) and Bloomberg Philanthropies (2\%). The main health-related causes targeted were infectious disease control and reproductive health \& family planning.

Figure 3. Philanthropic giving by sector, USD billion, 2013-15

\begin{tabular}{|c|c|c|}
\hline Health & & $9.6 ; 40 \%$ \\
\hline Population \& reproductive health & \multicolumn{2}{|l|}{$3.0 ; 12 \%$} \\
\hline Education & \multicolumn{2}{|l|}{$2.1 ; 9 \%$} \\
\hline Agriculture & \multicolumn{2}{|l|}{$1.9 ; 8 \%$} \\
\hline Government and civil society & \multicolumn{2}{|l|}{$1.7 ; 7 \%$} \\
\hline General environmental protection & \multicolumn{2}{|l|}{$1.1 ; 5 \%$} \\
\hline Other social infras. And services & \multicolumn{2}{|l|}{$0.9 ; 4 \%$} \\
\hline Humanitarian aid & \multicolumn{2}{|l|}{$0.7 ; 3 \%$} \\
\hline Banking and financial services & \multicolumn{2}{|r|}{$\begin{array}{l}\square \text { Other } \\
\square \text { Domestic }\end{array}$} \\
\hline Other & $2.2 ; 9 \%$ & BMGF \\
\hline
\end{tabular}

Foundations' giving in support of education (9\%) and agriculture (8\%) was significant too, with around USD 2 billion allocated to each over the three years. While the agriculture sector was boosted by 
significant support from the Bill and Melinda Gates Foundation (BMGF), the education sector was supported by a wider range of foundations, both international and domestic. Excluding the BMGF, the government \& civil society sector (including human rights, democratic participation and civil society development and ending violence against women and girls) was among the main sectors targeted by the philanthropic foundations ( $7 \%$ of the total).

Table 1. Top funders in education, agriculture and government $\&$ civil society sectors, USD million, 2013-15

\begin{tabular}{|l|r|}
\hline \multicolumn{2}{|c|}{ EDUCATION } \\
\hline MasterCard Fnd & 301.2 \\
\hline Vehbi Koç Fnd & 165.2 \\
\hline IKEA Fnd & 142.5 \\
\hline Telefónica Fnd & 138.9 \\
\hline Li Ka Shing Fnd & 132.6 \\
\hline
\end{tabular}

\begin{tabular}{|c|c|c|c|}
\hline \multicolumn{2}{|c|}{ AGRICULTURE } & \multicolumn{2}{|c|}{ GOV. \& CIVIL SOCIETY } \\
\hline BMGF & $1,294.5$ & Ford Fnd & 333.8 \\
\hline HGBF & 126.0 & OSF & 184.3 \\
\hline Tata Trusts & 78.3 & WFHF & 172.4 \\
\hline IKEA Fnd & 68.3 & Oak Fnd & 107.2 \\
\hline Gatsby Fnd & 31.9 & DPL & 100.0 \\
\hline
\end{tabular}

The Canadian MasterCard Foundation was the main funder in the education sector, followed by the Turkish Vehbi Koç Foundation and the Netherlands-based IKEA Foundation. After the Bill and Melinda Gates Foundation (BMGF), Howard G. Buffett Foundation (HGBF) and the Indian Tata Trusts were the most significant private foundations in the agriculture sector. The government and civil society sector mainly benefitted from funds extended by the Ford Foundation, Open Society Foundations (OSF), the William and Flora Hewlett Foundation (WFHF) and Oak Foundation.

\section{Africa was the main beneficiary region}

Africa was the main beneficiary region of philanthropic giving with USD 6.6 billion received over the period (28\% of the total), followed by Asia (USD 4.1 billion; 17\%), Latin America (USD 1.8 billion; $8 \%$ ) and Europe (USD 0.4 billion; 2\%). USD 10.8 billion (45\%) was unallocated by country or region, mainly reflecting the large share of philanthropic giving extended to organisations with a global/multi-region scope. A more detailed analysis of the main trends and allocations in Africa and Asia can be found on pages 10 and 11 .

Figure 4. Geographical distribution of foundations' giving, 2013-15

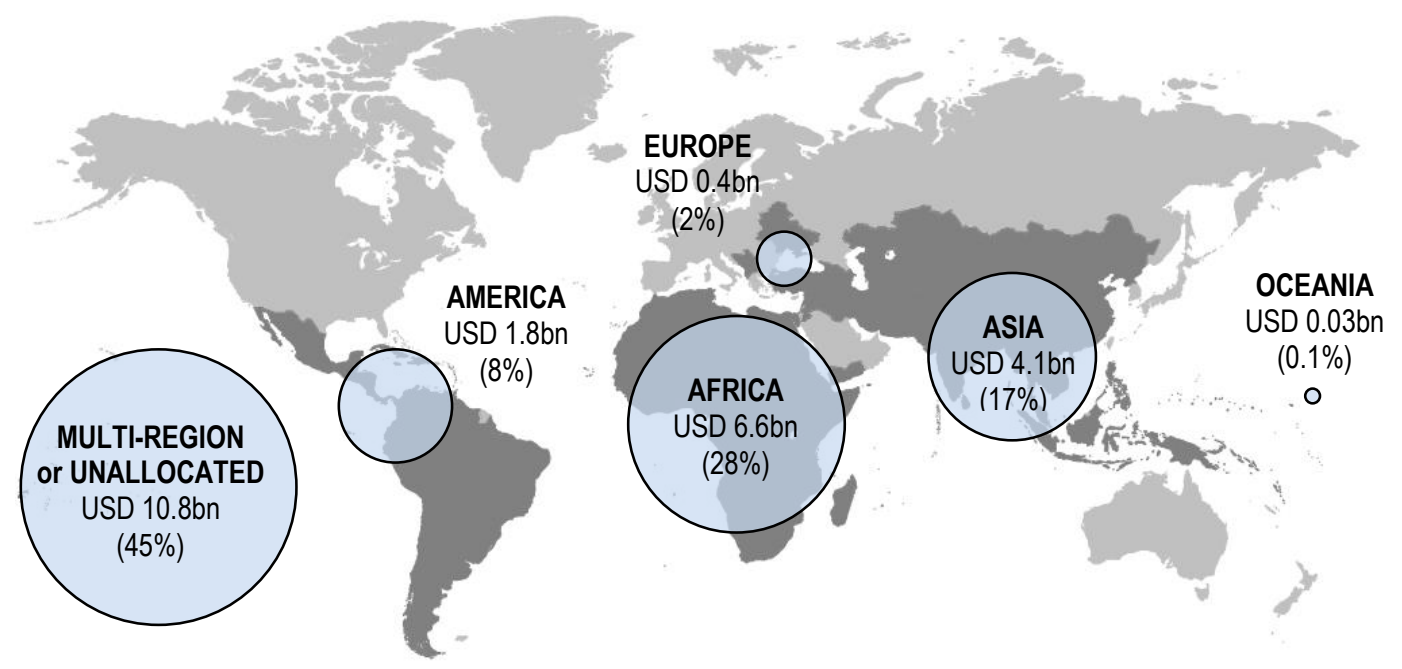




\section{BOX 1: Giving by foundations based in developing countries}

The survey also collected data on activities of 18 foundations based in low- and middle-income countries. Although the data collected on South-South philanthropic giving may not be fully representative, the results indicated that South-South giving amounted to USD 1.3 billion over 2013-15 (6\% of the three-year total). The largest of these foundations were located in Mexico (e.g. Carlos Slim Foundation), India (e.g. Tata Trusts), Turkey (e.g. Vehbi Koç Foundation), China (e.g. Li Ka Shing Foundation) and Brazil (e.g. Itaú Social Foundation).

Figure 5. Main foundations based in developing countries, USD million, 2013-15

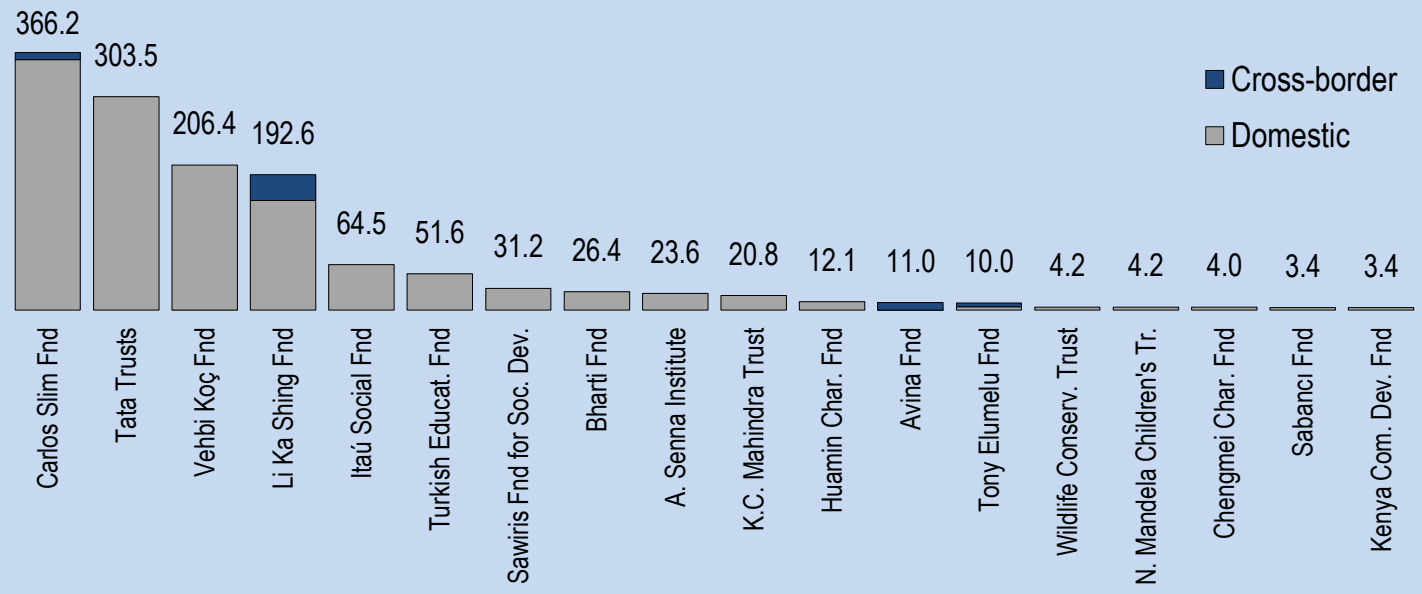

The survey revealed that foundations established in developing countries were mainly operating domestically. Only $5 \%$ of their giving was targeting other developing countries [e.g. Li Ka Shing Foundation, Avina Foundation (Panama), Carlos Slim Foundation and Tony Elumelu Foundation].

Foundations in developing countries mainly supported the education sector $(48 \%$ of the total; $83 \%$ of Turkish foundations' giving). The other main sectors of destination were health (18\%), other social infrastructure and services $(11 \%)$, agriculture, forestry and fishing $(7 \%)$ and general environmental protection $(6 \%)$.

Figure 6. Giving from foundations based in developing countries by sector, USD million, 2013-15

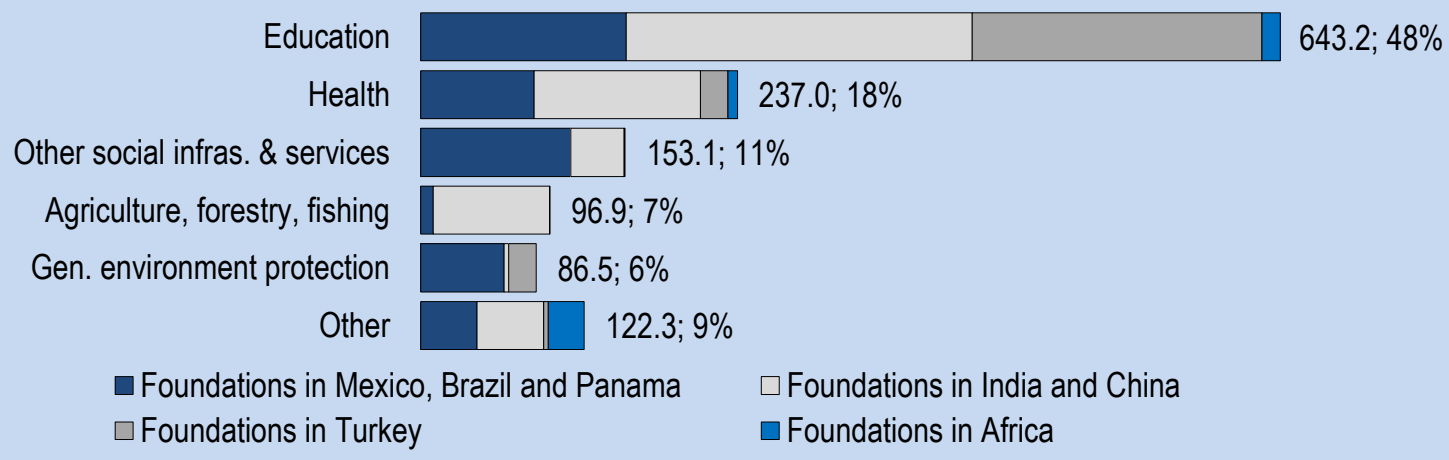

\section{Two-thirds of foundations' giving targeted middle-income countries}

The survey revealed that lower middle-income countries (LMICs) and upper middle-income countries (UMICs) received two-thirds of the country-allocable philanthropic giving. Only one-third of total giving targeted least development countries (LDCs) and other low-income countries (LICs). 
Figure 7. Philanthropic giving by income group, USD billion, 2013-15

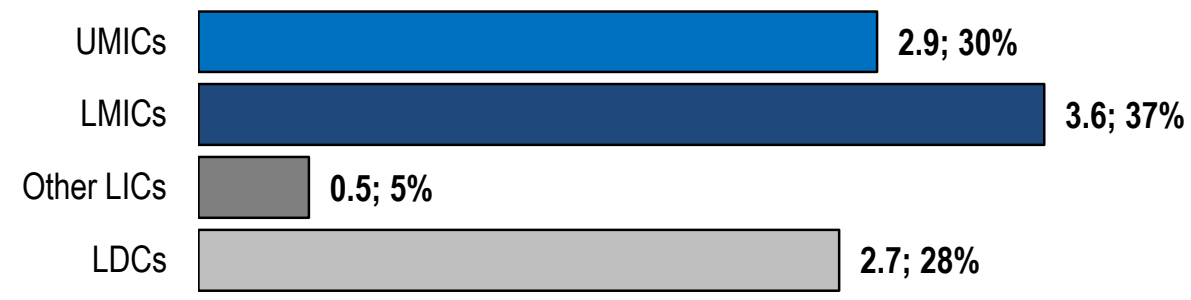

The top-10 beneficiary countries included seven middle-income countries, two LDCs and one other LIC. From a geographic point of view, 5 of the top 10 beneficiary countries were in Sub-Saharan Africa, two in Asia, two in Latin America and one in Europe.

Table 2. Top 10 beneficiary countries, 2013-15

\begin{tabular}{|r|l|l|l|r|r|}
\hline & $\begin{array}{c}\text { BENEFICIARY } \\
\text { COUNTRY }\end{array}$ & \multicolumn{1}{|c|}{$\begin{array}{c}\text { INCOME } \\
\text { GROUP }\end{array}$} & REGION & $\begin{array}{c}\text { AMOUNT } \\
\text { (USD million) }\end{array}$ & $\begin{array}{r}\text { SHARE IN } \\
\text { TOTAL GIVING }\end{array}$ \\
\hline 1. & India & LMICs & Asia & $1,588.9$ & $6.7 \%$ \\
\hline 2. & Nigeria & LMICs & Africa & 730.4 & $3.1 \%$ \\
\hline 3. & Mexico & UMICs & America & 596.3 & $2.5 \%$ \\
\hline 4. & China (PR of) & UMICs & Asia & 497.8 & $2.1 \%$ \\
\hline 5. & Ethiopia & LDCs & Africa & 482.8 & $2.0 \%$ \\
\hline 6. & South Africa & UMICs & Africa & 416.6 & $1.7 \%$ \\
\hline 7. & Kenya & Other LICs & Africa & 397.8 & $1.7 \%$ \\
\hline 8. & Brazil & UMICs & America & 329.2 & $1.4 \%$ \\
\hline 9. & Tanzania & LDCs & Africa & 322.0 & $1.3 \%$ \\
\hline 10. & Turkey & UMICs & Europe & 314.5 & $1.3 \%$ \\
\hline
\end{tabular}

\section{Most of philanthropic giving was channelled through intermediaries}

$50 \%$ of total philanthropic giving in 2013-15 was channelled through NGOs, civil society, PPPs and networks and the for-profit private sector, followed by universities, research and education institutes $(22 \%)$ and the multilateral system (19\%). Only $3 \%$ of the total giving was executed by the foundations themselves.

\section{Figure 8. Philanthropic giving by main channel of delivery, USD billion, 2013-15}

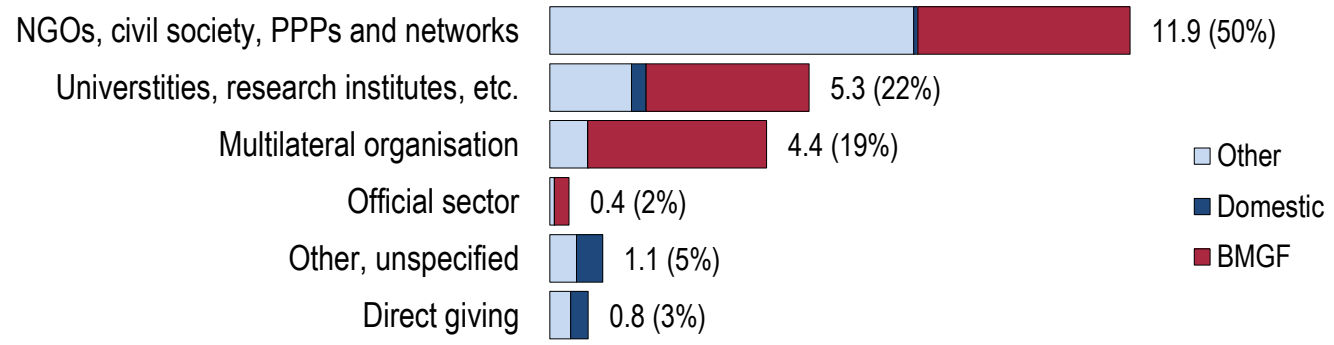

Giving channelled through multilateral organisations is mainly by the Bill and Melinda Gates Foundation. For example, in 2015 the foundation pledged a core contribution to Gavi, the Vaccine Alliance, for its 2016-20 operations amounting to USD 1.55 billion. Most of the other foundations made use of the NGOs and civil society to channel their funds. Foundations based in developing countries rather channelled their giving through research institutes or did not make use of any intermediary (e.g. scholarships to individuals and activities of operational foundations). 


\section{Philanthropic giving for Africa \\ USD 6.6 billion (28\% of total giving over 2013-15)}

Figure 9. Foundations most active in Africa, USD million, 2013-15

$3,232.2^{*}$

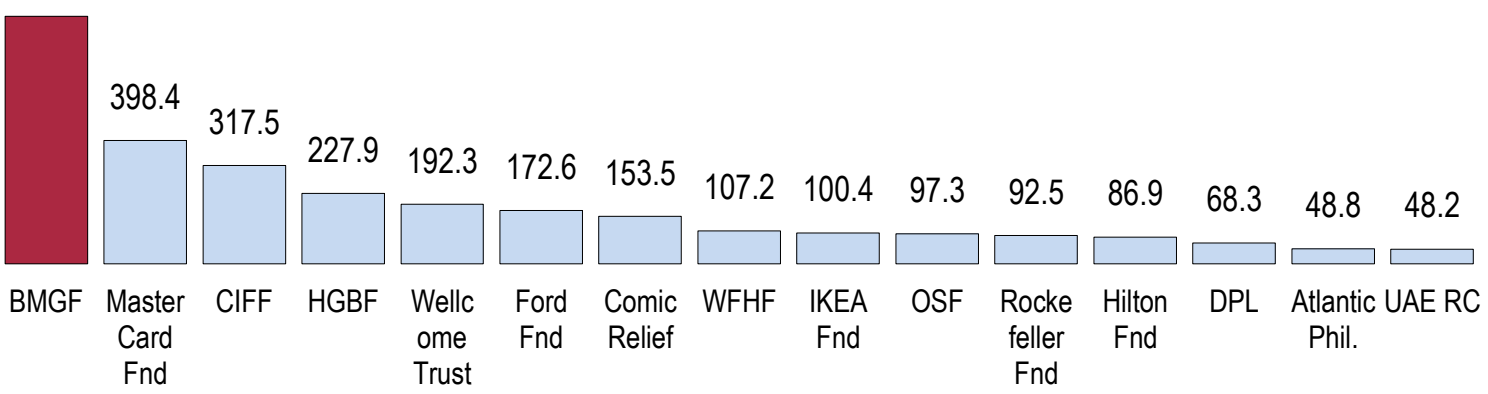

*The column size for the BMGF was reduced for illustrative purposes

Figure 10. Main beneficiary countries in Africa, USD million, 2013-15

$28 \%$

of which for children and youth

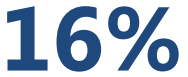

of which for gender,

women \& girls

empowerment

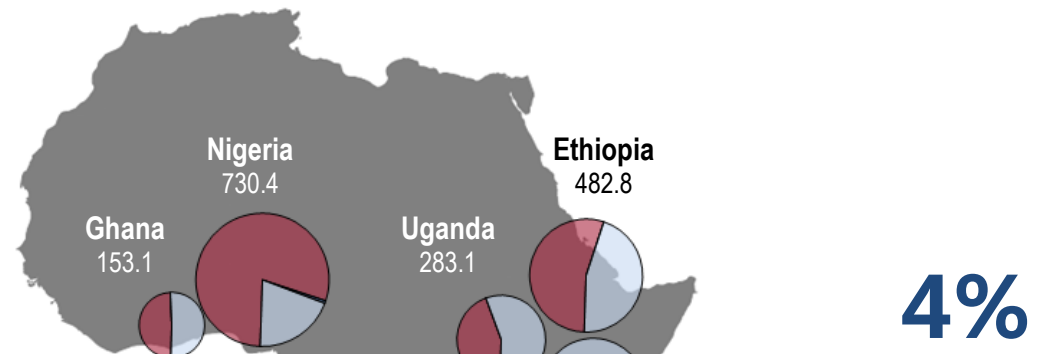

for combating climate change

Figure 11. Main sectors targeted in Africa, USD million, 2013-15

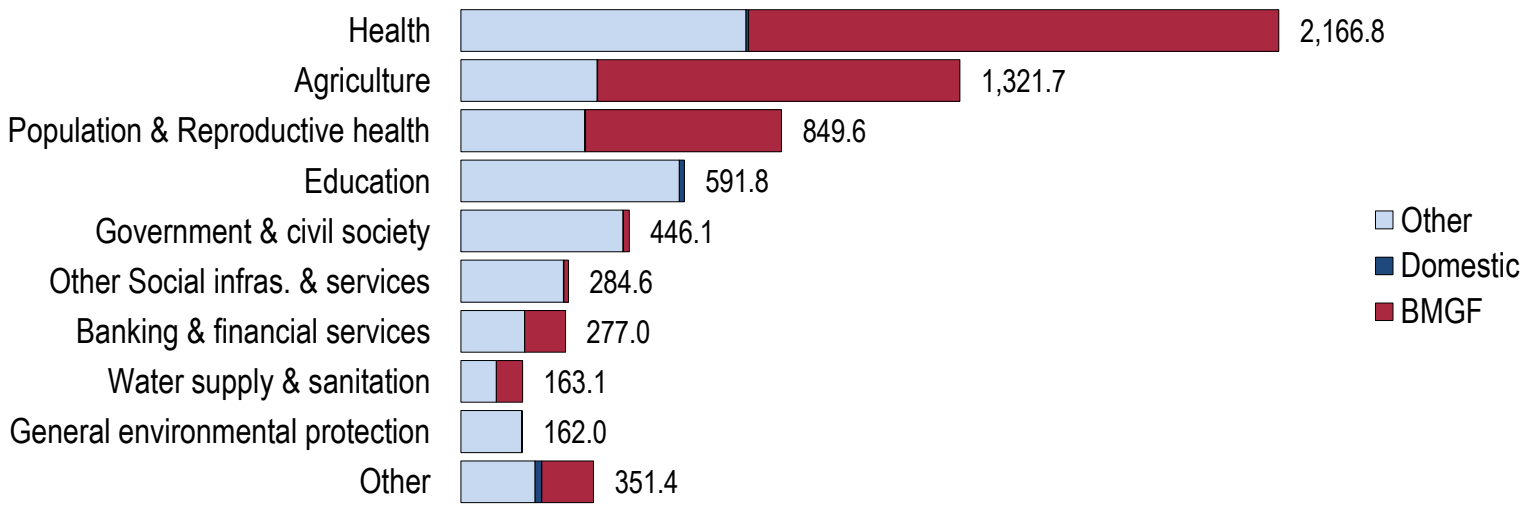




\section{Philanthropic giving for Asia \\ USD 4.1 billion (17\% of total giving over 2013-15)}

Figure 12. Foundations most active in Asia, USD million, 2013-15

$1,498.9^{*}$

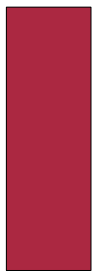

BMGF

303.5

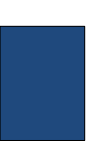

Tata Trusts

\subsection{8 .2}
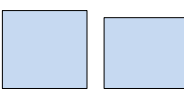

Fnd

\section{1}
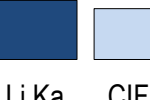

Shing

Fnd

Figure 13. Main beneficiary countries in Asia, USD million, 2013-15

\section{$36 \%$}

of which for children and youth

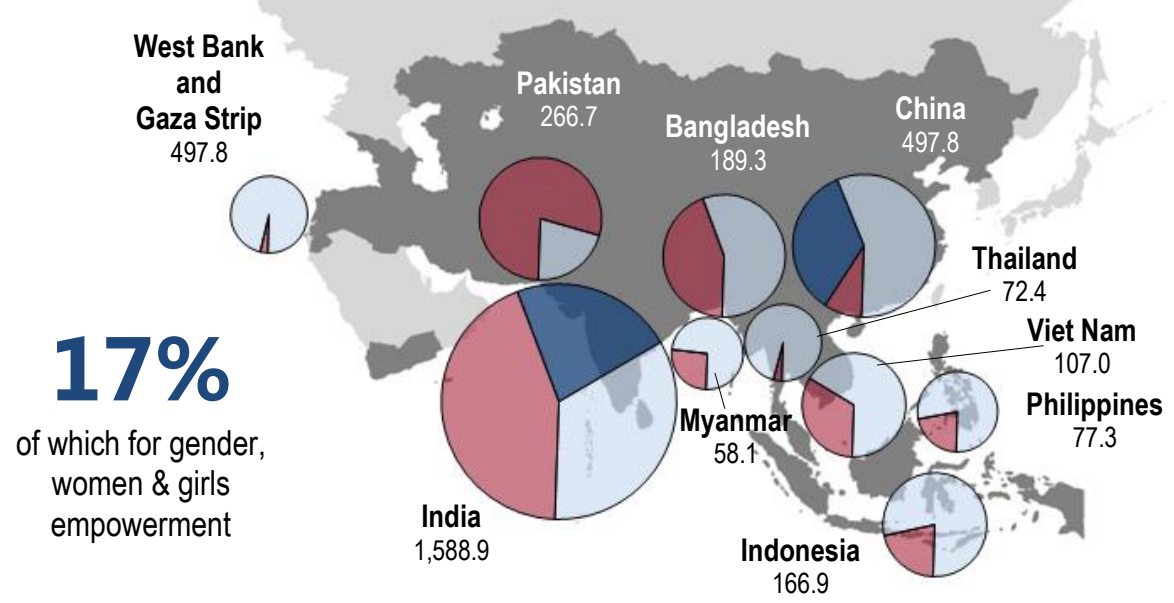

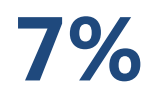

for combating climate change

Figure 14. Main sectors targeted in Asia, USD million, 2013-15

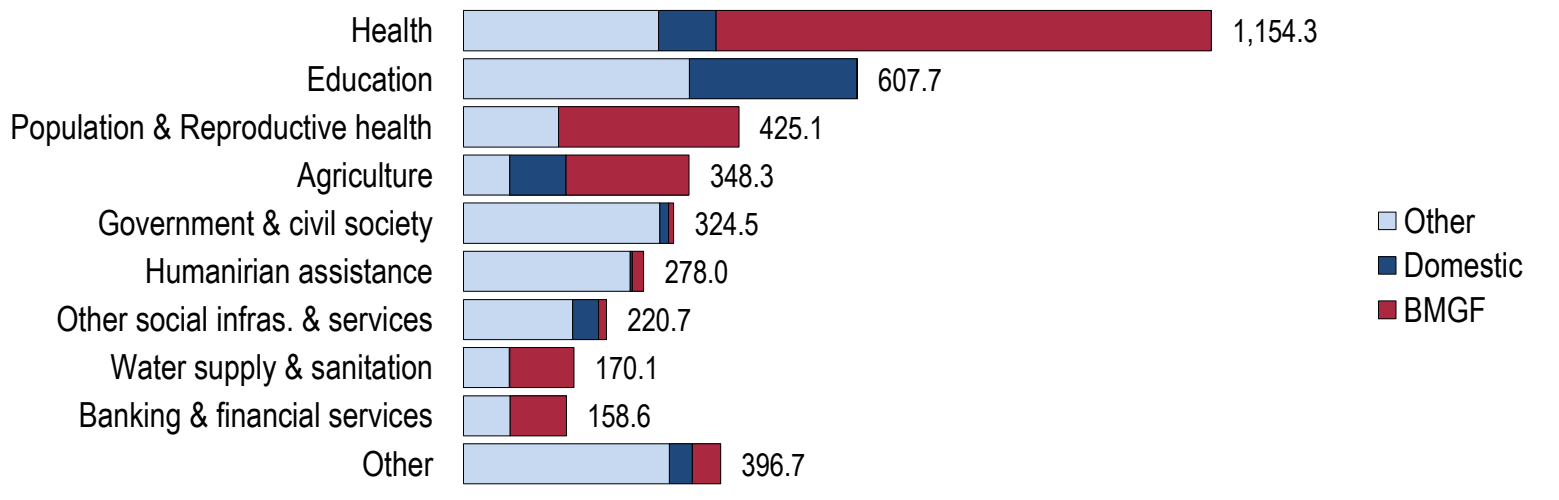




\section{Children and youth were the most targeted population group}

USD 7.5 billion (31\% of the three-year total) was extended in support of children and youth, mostly through health $\&$ reproductive health $(57 \%$, e.g. infectious diseases control, family planning and basic nutrition) and education activities (27\%). Almost half of these funds (45\%) were provided by the Bill and Melinda Gates Foundation, followed by the Children's Investment Fund Foundation (8\%), IKEA Foundation and the MasterCard Foundation (5\% each).

\section{Figure 15. Philanthropic giving by main population group, 2013-15}

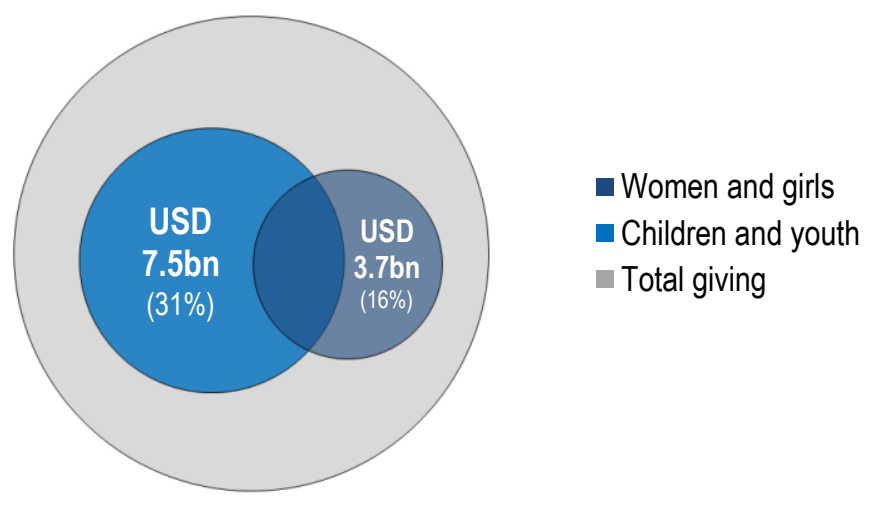

Approximately USD 3.7 billion (16\% of the three-year total) targeted women and girls, most significantly through activities in the health \& reproductive health $(74 \%$, e.g. reproductive health, family planning and infectious diseases) but also government \& civil society sectors ( $10 \%$, e.g. human rights, women's equality organisations and institutions, ending violence to women $\&$ girls incl. FGM, and human rights). The Bill and Melinda Gates Foundation was the main actor also in this field (43\% of giving to women and girls), followed by the Susan T. Buffett Foundation (19\%), Children's Investment Fund Foundation, Ford Foundation, Dutch Postcode Lottery and the William and Flora Hewlett Foundation (3\% each).

\section{Foundations can play an important role in achieving SDG $3^{\text {viii }}$}

The survey also aimed at providing rough estimates of foundations' possible contribution to financing the SDGs. This information was mainly based on sectoral allocation and descriptive information (see Annex 4). Overall, as shown in figure 17, foundations seem to have the potential to help developing countries fund the SDG 3 ("Good Health and Well-being"). However, the survey results also indicated that foundations' activities may support the SDG 10 ("Reduced Inequalities"), SDG 4 ("Quality Education"), SDG 5 ("Gender Equality"), SDG 9 ("Industry, Innovation and Infrastructure") and SDG 2 ("Zero Hunger"). ${ }^{\text {ix }}$ When excluding the Bill and Melinda Gates Foundation from the dataset, SDG 16 ("Peace, Justice and Strong Institutions") also emerges as a significant area of foundations' support. On contrary, SDG 6 ("Clean Water and Sanitation"), SDG 7 ("Affordable and Clean Energy"), SDG 12 ("Responsible Consumption and Production"), SDG 14 ("Life below Water"), and SDG 17 ("Partnerships for the Goals") do not seem to fall under the main funding priorities of the private foundations.

Figure 16. Top 6 SDGs to which foundations contribute

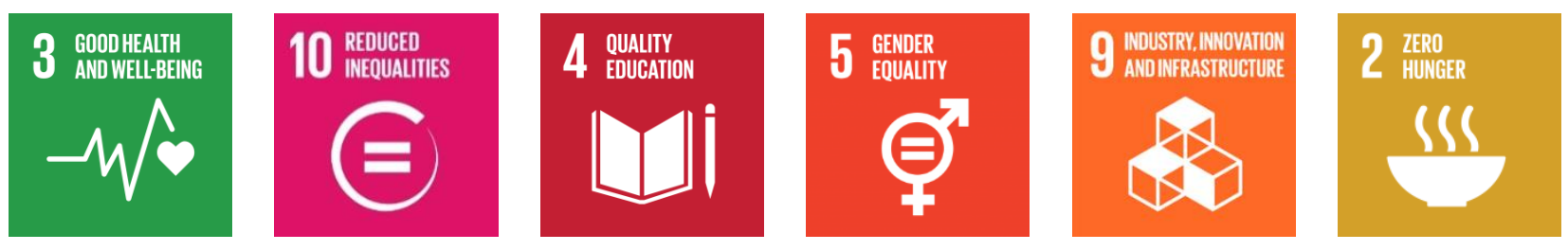

PRIVATE FOUNDATIONS' GIVING FOR DEVELOPMENT IN 2013-15

Ongoing efforts to better reflect private philanthropic giving in OECD-DAC statistics on development finance 


\section{Figure 17. Foundations' contribution to the SDGs (as \% of total giving)*}

All foundations

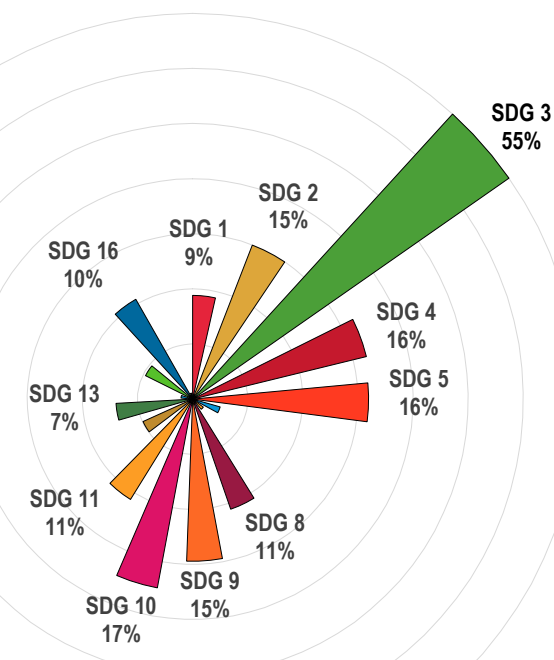

Foundations other than the BMGF

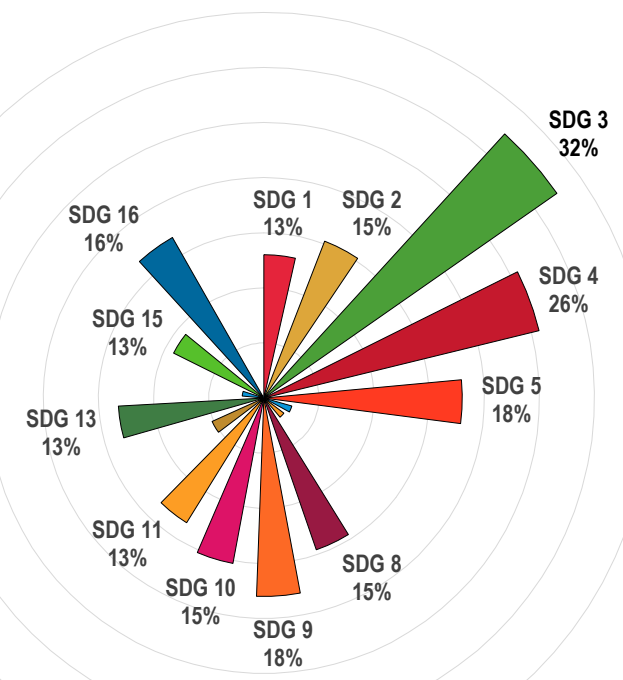

The size of the SDG 3 arrow in this figure was reduced for illustrative purposes

*The sum of percentages per SDG is higher than $100 \%$ due to the overlap between individual SDGs, i.e. a single activity may contribute to multiple SDGs.

\section{References}

OECD (2018), Annex 2 List of ODA-eligible international organisations, www.oecd.org/dac/stats/annex2.htm. OECD (2018), DAC List of ODA Recipients, www.oecd.org/dac/stats/daclist.htm.

\section{Notes}

'Donations by "rulers" (members of ruling families in relevant Arab countries) are considered official.

ii Analysis of the results of the qualitative questionnaire has been carried out by netFWD and is published in: OECD (2018), Private Philanthropy for Development, OECD Publishing, Paris, forthcoming.

iii Form 990-PF is used to figure the tax based on investment income, and report charitable distributions and activities to the Internal Revenue Service of the United States. It also serves as a substitute for the section 4947(a)(1) nonexempt charitable trust's income tax return, Form 1041, U.S. Income Tax Return for Estates and Trusts, when the trust has no taxable income. In general, reporting through form 990-PF is obligatory for exempt private foundations, taxable private foundations and organisations in the process of becoming legally private foundations. US Department of the Treasury, IRS (2018), 2017 Instructions for Form 990-PF, www.irs.gov/pub/irs-pdf/i990pf.pdf.

iv Grants are defined as transfers in cash or in kind for which no legal debt is incurred by the recipient.

${ }^{\vee}$ Non-grant charitable activities include programme-related investments (PRI), mission-related investments (MSI) and their equivalents administered with the promotion of the economic development and welfare of developing countries.

${ }^{v i}$ For example Brazil, Egypt, India, Japan, Kenya, Mexico, Nigeria, Panama, People's Republic of China, South Africa and United Arab Emirates.

vii The full sector title is "population policies/programmes and reproductive health".

viii For more details refer to Annex 4: Estimation of foundations' contribution to the SDGs.

${ }^{i x}$ However, the mapping may overestimate foundations' contribution to some SDGs with a typically horizontal or crosscutting nature, such as SDG 9 and SDG 10. 


\section{OECD EFFORTS TO ENHANCE DAC STATISTICS ON PRIVATE PHILANTHROPY}

The primary objective of the OECD Development Co-operation Directorate (DCD) is to contribute to developing better policies for better lives through transparent data on development finance and improved development co-operation practices and policies. The DCD also serves as the Secretariat for the Development Assistance Committee (DAC). For over 50 years, the OECD-DAC has grouped the world's most significant ODA providers, defining and monitoring global standards in key areas of development. Its mandate is to "promote development co-operation and other relevant policies so as to contribute to implementation of the 2030 Agenda for Sustainable Development, including sustained, inclusive and sustainable economic growth, poverty eradication, improvement of living standards in developing countries, and to a future in which no country will depend on aid".

The OECD-DCD also supports the UN in monitoring the SDGs and has played a role in forging major international development commitments, including the SDGs and the Paris Declaration on Aid Effectiveness.

This section describes the current scope and coverage of the OECD-DAC statistics on development finance and the on-going efforts to improve data coverage and relevance on development finance beyond ODA, with a special focus on private philanthropy.

\section{COVERAGE OF OECD-DAC STATISTICS ON DEVELOPMENT FINANCE}

Over the last decade, the development finance landscape has undergone profound changes with innovative financial approaches to mobilise private finance but also new players such as private philanthropic foundations. In order to properly reflect these changes and remain a relevant source of information for policymakers and analysts, the OECD has worked on means to enhance the DAC statistical system on development finance beyond ODA. This work does not only include constant updates of the database architecture, but also statistical engagement with emerging development finance providers from both the official and private sectors.

\section{Flows covered}

Table 3 below gives an overview of the main resource flows covered in OECD-DAC statistics. Data are collected on both official and private flows, both concessional and non-concessional. For official flows the major distinction lies between ODA and other official flows (OOF), while private flows are broken down into flows at market terms and charitable grants. Such flows also include contributions to multilateral development agencies, which are official bodies themselves. The outflows from multilateral agencies are the subject of a separate data collection aimed at providing a more complete picture of developing countries' receipts.

\section{Table 3. Flows covered by the DAC statistics}

\section{A. Flows from countries}

\begin{tabular}{|c|c|c|}
\hline & Concessional & Non-concessional \\
\hline Official & $\begin{array}{l}\text { Official } \\
\text { Development } \\
\text { Assistance (ODA) } \\
\text { flows }\end{array}$ & $\begin{array}{l}\text { Other Official Flows } \\
\text { (OOF), } \\
\text { Officially supported } \\
\text { export credits }\end{array}$ \\
\hline Prive & $\begin{array}{l}\text { NGO, foundations } \\
\text { and other } \\
\text { charitable flows }\end{array}$ & $\begin{array}{l}\text { Private flows at market } \\
\text { terms }\end{array}$ \\
\hline
\end{tabular}

\section{B. Flows from multilateral organisations}

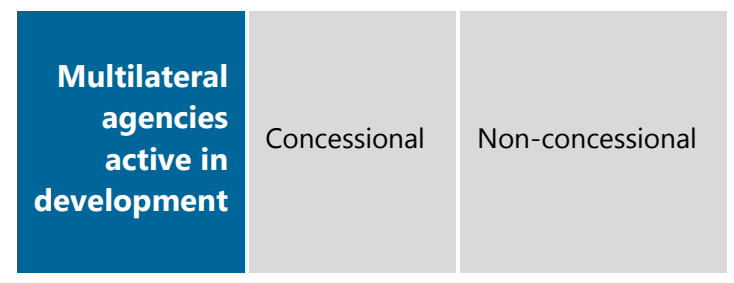


To avoid duplication of data collections, OECD analyses on the big picture of external resource flows to developing countries may also include complementary information from other datasets - for which standards and concepts are compatible with those of the DAC - such as the World Bank statistics on personal remittances (see figure 19).

Figure 18. Big picture of external finance flows to developing countries USD trillion, 2000-15, 2 years moving average ${ }^{x}$

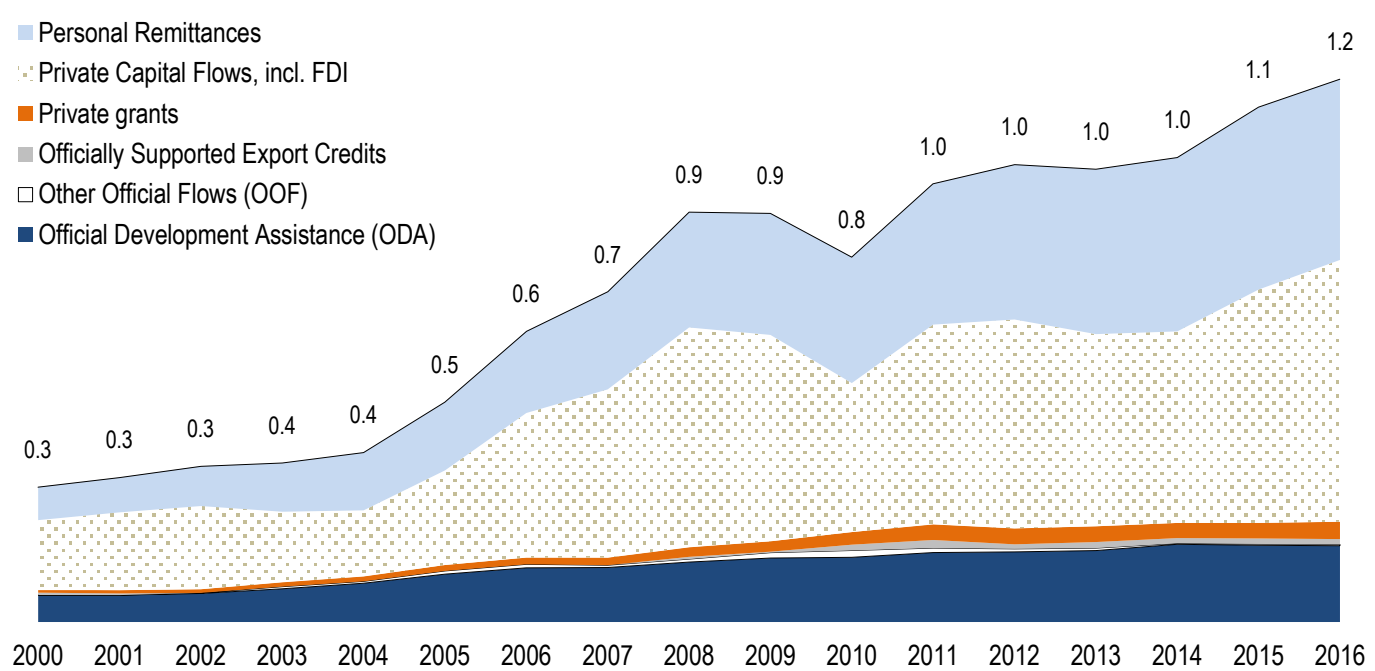

\section{Who reports?}

To date, the OECD statistics on development finance include detailed data from 30 DAC members, 20 non-DAC countries, 39 multilateral organisations and 4 philanthropic foundations. Statistical engagement with private philanthropic foundations was initiated in 2009 when the Bill and Melinda Gates Foundation became the first private donor reporting to the OECD on its grant making as well as programme-related investments (PRIs) at the activity level, following the DAC statistical standards on measuring development finance flows. In 2017, the United Postcode Lotteries (the Dutch Postcode Lottery, Swedish Postcode Lottery and People's Postcode Lottery) followed the example of the Bill and Melinda Gates Foundation and published their grantmaking data for the first time through the OECD online database.

Beyond data publication, the OECD-DAC statistical framework offers development co-operation actors a central platform for improving transparency and accountability. For example, the OECD facilitates communication between data providers and data users: it advises on data quality and standardisation, ensures high data quality (including comparability) and provides and administers data dissemination platforms. Considering data as a global public good, the OECD does not claim ownership over the data and makes them available to the public for free. Data reported to the OECD-DAC also constitute primary inputs to a number of OECD flagship publications, such as Development Co-operation Report (DCR). 


\section{BOX 2: Why engage in regular reporting with the OECD? Saara Romu, Senior Program Officer at Bill \& Melinda Gates Foundation}

The Bill \& Melinda Gates Foundation has a deep respect for data and the work of partners such as the OECD who gather and share data in an effort to inform and promote effective decision making. Our co-chairs are proud "Data Geeks" because they know that data plays a vital role in improving lives around the world. When the UN High-Level Panel of Eminent Persons called for a data revolution, the foundation agreed yet identified a need to further define what should be done to ensure that countries around the world could deliver on the Sustainable Development Goals.

Committing to sharing information about commitments \& disbursements using the standards developed by the OECD-DAC is one step. We encourage others to join us in this commitment to drive transparency and analysis of planned and actual aid across the private and public sectors in furtherance of SDGs.

We are also working with the OECD Partnership for Development of Statistics in the $21^{\text {st }}$ Century (Paris21) to provide guidance, which they published as the Road Map for a Country-led Data Revolution. This road map and other data-related resources that the foundation supports have helped several development actors and foundations consider how they should support improvement of data in partnership with countries. The innovative approaches undertaken by OECD to support better and more comprehensive data will make the world more equitable and accelerate achievement of the SDGs.

The OECD-DCD has developed longstanding experience in collecting data and publishing statistics on development finance from multiple sources (DAC members, non-DAC providers, private foundations). Its expertise, reputation and added value are based on:

- full comparability of statistics from a variety of data providers, also covering a wide range of activities from ODA flows to private philanthropic giving (see table 18). Comparability is ensured by applying a single set of international statistical standards (e.g. definition, scope, sector and instrument classifications).

- data quality and reliability, ensured by extensive quality checks, at the activity level and by statistical experts.

- full transparency, with most data reported at the activity level, on both commitment and disbursement $^{\mathrm{xi}}$ (some exceptions exist for confidential activities).

The availability of a comparable and reliable source of information on development finance flows is recognised as a critical driver of aid coordination among development actors and also as contributing to achieving results.

\section{OECD-DAC REPORTING CYCLE}

The process of data collection follows a 12-month cycle. For private philanthropic foundations, the cycle usually starts in Q1/Q2 when the OECD Secretariat invites all data providers to share their completed Creditor Reporting System (CRS) reporting template on development finance flows provided during the preceding year. Once the data have been received, the Secretariat carefully checks the quality of reported activities, including their compliance with international development finance standards necessary for data comparability. Having consolidated the annual data submission, the Secretariat publishes it through the OECD central database system OECD.stat. ${ }^{\text {xii }}$ The online database is updated four times a year (in principle April, June, September, and December). 


\section{Figure 19. Reporting cycle}

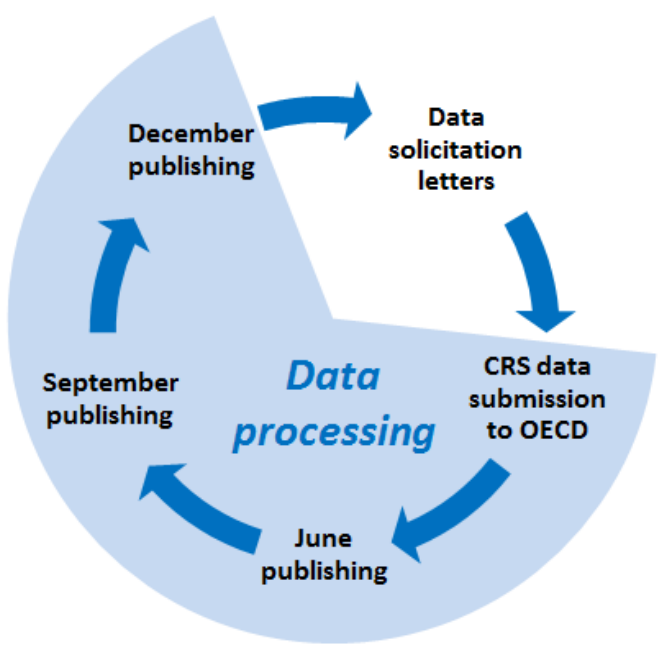

\section{DATA DISCLOSURE POLICY}

OECD-DCD usually recommends that rules of data disclosure on private philanthropic flows for development follow the same principles as for ODA, i.e. full data disclosure at the activity level. However, the system can also be flexible and present semi-aggregate information (e.g. by recipient and sector) to accommodate specific confidentiality constraints.

\section{BOX 3. Highlights on United Postcode Lotteries' giving in 2016}

In 2017, the United Postcode Lotteries (UPL) started engaging in regular reporting to the OECD on their development activities using the OECD-DAC standards and format. According to the UPL report on 2016 flows (available on OECD.stat), the lotteries gave USD 324.5 million for development, $68 \%$ of which was extended by the Dutch Postcode Lottery, $25 \%$ by the Swedish Postcode Lottery and $7 \%$ by the People's Postcode Lottery (United Kingdom). The data further show that:

- $97 \%$ of the funds were cross-border flows, while the remaining $3 \%$ related to development awareness and refugees in donor countries.

- The main channels of delivery used by the UPL were the NGOs and other civil society organisations in provider or high-income countries (74\% of total funding), followed by international NGOs (12\%; e.g. Médecins sans Frontières and Amnesty International), multilateral organisations (9\%; UNICEF, UNHCR and World Food Programme) and NGOs in developing countries (4\%).

- Most of UPL's funding was in the form of unearmaked contributions (82\%) to the above-mentioned intermediaries; only $18 \%$ was extended as project-type interventions.

- $14 \%$ of the funds could be allocated by region, mainly in favour of Africa and Latin America.

- Although $42 \%$ of the funds supported social infrastructure and services, the lotteries were also major financiers of humanitarian assistance (19\%) and environmental protection (17\%).

- In addition, the data indicated that $29 \%$ of the funds were allocated in support of the environment, $26 \%$ for biodiversity conservation, $22 \%$ for climate change mitigation, adaptation or both and $20 \%$ for reproductive, maternal, new-born and child health (RMNCH). 


\section{Notes}

${ }^{x}$ Sources: Official Development Assistance (ODA), Other Official Flows (OOF), officially supported export credits and Private grants, OECD-DAC statistics on net disbursements. Net private grants cover gross outflows from NGOs and civil society minus support received from official sector. Personal remittances and private capital flows, World Bank. Private capital flows include net FDI and portfolio investments. Amounts are in current prices.

${ }^{x i}$ While data on commitments shed light on policy intentions, tracking net disbursements informs on actual aid allocations.

${ }^{x i i}$ See stats.oecd.org and stats.oecd.org/qwids.

\section{References}

OECD (2018), Development Co-operation Report, OECD Publishing, Paris, dx.doi.org/10.1787/20747721.

OECD (2018), OECD.stat, stats.oecd.org (accessed 28 February 2018).

OECD (2018), QWIDS, Query Wizard for International Development Statistics, stats.oecd.org/qwids (accessed 28 February 2018).

PARIS21 (2015), A Road Map for a Country-led Data Revolution, OECD Publishing, Paris, dx.doi.org/10.1787/9789264234703-en.

WB (2018), "Personal remittances, received (current US\$)", World Bank data,

data.worldbank.org/indicator/BX.TRF.PWKR.CD.DT (accessed 28 February 2018). 


\section{ANNEX 1: GIVING BY PROVIDER}

\begin{tabular}{|c|c|c|c|c|c|c|}
\hline 을 을 & Name of private provider & $\begin{array}{c}\text { Main } \\
\text { office } \\
\text { location* }\end{array}$ & 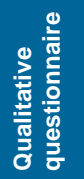 & 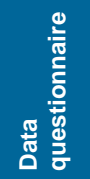 & 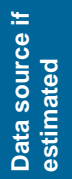 & $\begin{array}{l}\text { Total giving, } \\
\text { 2013-2015, } \\
\text { USD '000 }\end{array}$ \\
\hline \multirow{43}{*}{ 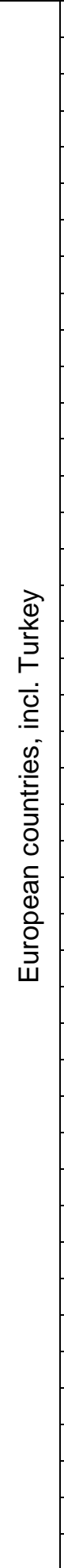 } & Avina Foundation (Switzerland) & SUI & Yes & - & - & - \\
\hline & Bernard van Leer Foundation & NLD & Yes & Yes & - & $9,377.9$ \\
\hline & Bertelsmann Foundation & Germany & Yes & Yes & - & $4,417.4$ \\
\hline & Big Lottery Fund & UK & Yes & Yes & - & $71,821.2$ \\
\hline & C\&A Foundation & SUI & Yes & Yes & - & $53,731.8$ \\
\hline & Calouste Gulbenkian Foundation & Portugal & Yes & Yes & - & $8,909.9$ \\
\hline & Chanel Foundation & France & Yes & Yes & - & $3,036.7$ \\
\hline & Children's Investment Fund Foundation & UK & Yes & Yes & - & $747,854.8$ \\
\hline & Cariplo Foundation & Italy & - & Estim. & Web & $4,056.0$ \\
\hline & Comic Relief & UK & - & Estim. & Web & $172,414.7$ \\
\hline & Daniel \& Nina Carasso Foundation & France & Yes & Yes & - & $3,103.3$ \\
\hline & Dutch Postcode Lottery & NLD & Yes & Yes & - & $666,368.6$ \\
\hline & EDF Foundation & France & Yes & Yes & - & $6,077.2$ \\
\hline & Fondation de France & France & Yes & Yes & - & $14,654.8$ \\
\hline & Gerda Henkel Foundation & Germany & Yes & Yes & - & $10,512.1$ \\
\hline & Grameen Crédit Agricole Foundation & France & Yes & Yes & - & $57,197.4$ \\
\hline & H\&M Foundation & Sweden & Yes & Yes & - & $52,722.5$ \\
\hline & Haci Ömer Sabanci Foundation & Turkey & Yes & Yes & - & $3,380.0$ \\
\hline & Human Dignity Foundation & SUI & Yes & Yes & - & $20,378.7$ \\
\hline & IKEA Foundation & NLD & Yes & Yes & - & $405,777.3$ \\
\hline & Jacobs Foundation & SUI & Yes & Yes & - & $8,205.2$ \\
\hline & King Baudouin Foundation & Belgium & Yes & Yes & - & $10,691.7$ \\
\hline & La Caixa Banking Foundation & Spain & Yes & Yes & - & $33,883.7$ \\
\hline & Lloyd's Register Foundation & UK & Yes & Yes & - & $3,655.6$ \\
\hline & MAVA Foundation & SUI & Yes & Yes & - & $74,638.6$ \\
\hline & Mérieux Foundation & France & Yes & Yes & - & $18,564.2$ \\
\hline & Novartis Foundation & SUI & Yes & Yes & - & $9,926.1$ \\
\hline & Oak Foundation & SUI & Yes & Yes & - & $270,805.6$ \\
\hline & Philips Foundation & NLD & - & Estim. & AR & $2,365.7$ \\
\hline & Queen Elizabeth Diamond Jubilee Trust & UK & Yes & Yes & - & $25,806.4$ \\
\hline & Robert Bosch Foundations & Germany & - & Estim. & AR & $37,604.3$ \\
\hline & Sainsburys Family Charitable Trusts: Gatsby Charitable Foundation & UK & Yes & Yes & - & $47,833.9$ \\
\hline & Sainsburys Fam. Char. Tr.: Indigo Trust & UK & - & Yes & - & $2,601.9$ \\
\hline & Sainsburys Fam. Char. Tr.: Staples Trust, True Colours Trusts & UK & - & Yes & - & 222.0 \\
\hline & Sanofi Espoir Foundation & France & Yes & Yes & - & $13,785.8$ \\
\hline & Shell Foundation & UK & - & Estim. & $A R$ & $98,047.0$ \\
\hline & Siemens Foundation & Germany & Yes & Yes & - & $27,619.4$ \\
\hline & Sigrid Rausing Trust & UK & Yes & Yes & - & $78,428.2$ \\
\hline & Small Foundation & Ireland & Yes & Yes & - & $4,437.4$ \\
\hline & Stars Foundation & UK & Yes & Yes & - & $4,780.0$ \\
\hline & Swiss Re Foundation & SUI & Yes & - & - & - \\
\hline & Telefónica Foundation & Spain & Yes & Yes & - & $171,471.8$ \\
\hline & Turkish Educational Foundation & Turkey & - & Estim. & $\mathrm{AR}$ & $51,605.4$ \\
\hline
\end{tabular}

PRIVATE FOUNDATIONS' GIVING FOR DEVELOPMENT IN 2013-15

Ongoing efforts to better reflect private philanthropic giving in OECD-DAC statistics on development finance 


\begin{tabular}{|c|c|c|c|c|c|c|}
\hline 오을 & Name of private provider & $\begin{array}{l}\text { Main } \\
\text { office } \\
\text { location* }\end{array}$ & 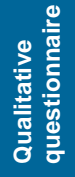 & 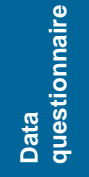 & 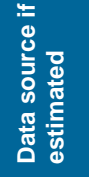 & $\begin{array}{l}\text { Total giving, } \\
\text { 2013-2015, } \\
\text { USD ‘ } 000\end{array}$ \\
\hline & UBS Optimus Foundation & SUI & Yes & Yes & - & $134,481.1$ \\
\hline & Vehbi Koç Foundation & Turkey & - & Estim. & AR & $206,443.6$ \\
\hline & Veolia Foundation & France & Yes & Yes & - & $3,048.4$ \\
\hline & Volkswagen Foundation & Germany & - & Estim. & $A R$ & $44,192.5$ \\
\hline & Wellcome Trust & UK & Yes & Yes & - & $393,718.3$ \\
\hline & World Diabetes Foundation & Denmark & Yes & Yes & - & $31,412.9$ \\
\hline & \multicolumn{5}{|l|}{ European countries, total } & $4,126,069.0$ \\
\hline \multirow{38}{*}{ 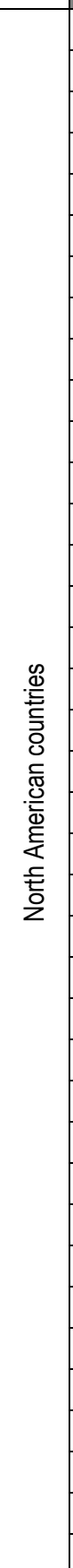 } & Abbott Fund & USA & - & Estim. & IRS & $21,252.7$ \\
\hline & Alcoa Foundation & USA & - & Estim. & IRS & $11,434.0$ \\
\hline & Andrew W. Mellon Foundation & USA & Yes & Yes & - & $35,313.2$ \\
\hline & Annenberg Foundation & USA & - & Estim. & Web & $4,329.5$ \\
\hline & Arcus Foundation & USA & Yes & Yes & - & $55,062.5$ \\
\hline & Atlantic Philanthropies & USA & - & Estim. & Web & $74,708.2$ \\
\hline & Bank of America Charitable Foundation & USA & - & Estim. & IRS & $42,806.0$ \\
\hline & Barr Foundation & USA & - & Estim. & Web & $24,216.8$ \\
\hline & Bill and Melinda Gates Foundation & USA & Yes & Yes & - & $11,627,212.9$ \\
\hline & Bloomberg Philanthropies & USA & - & Estim. & IRS & $417,655.4$ \\
\hline & Blue Moon Fund & USA & - & Estim. & IRS & $27,696.5$ \\
\hline & Bristol-Myers Squibb Foundation & USA & - & Estim. & IRS & $19,933.4$ \\
\hline & Carnegie Corporation of New York & USA & Yes & Yes & - & $54,937.8$ \\
\hline & Caterpillar Foundation & USA & Yes & Yes & - & $60,462.2$ \\
\hline & Charles Stewart Mott Foundation & USA & Yes & Yes & - & $41,943.0$ \\
\hline & Christensen Fund & USA & - & Estim. & Web & $30,823.6$ \\
\hline & Citi Foundation & USA & Yes & Yes & - & $50,887.2$ \\
\hline & Coca-Cola Foundation & USA & - & Estim. & IRS & $112,660.2$ \\
\hline & Conrad N. Hilton Foundation & USA & - & Estim. & Web & $133,507.5$ \\
\hline & Dalio Foundation & USA & - & Estim. & IRS & $75,596.0$ \\
\hline & David and Lucile Packard Foundation & USA & - & Estim. & Web & $284,464.9$ \\
\hline & Doris Duke Charitable Foundation & USA & - & Estim. & Web & $5,414.2$ \\
\hline & eBay Foundation & USA & - & Estim. & IRS & $1,608.0$ \\
\hline & ExxonMobil Foundation & USA & - & Estim. & IRS & $74,160.3$ \\
\hline & FHI Foundation & USA & Yes & Yes & - & $8,590.0$ \\
\hline & Ford Foundation & USA & Yes & Yes & - & $613,411.0$ \\
\hline & General Electric Foundation & USA & - & Estim. & IRS & $66,843.8$ \\
\hline & Goldman Sachs Charitable Gift Fund & USA & - & Estim. & IRS & $11,893.3$ \\
\hline & Goldman Sachs Foundation & USA & - & Estim. & IRS & $24,981.4$ \\
\hline & Google Foundation and L. Page donations & USA & - & Estim. & IRS & $83,726.6$ \\
\hline & Gordon and Betty Moore Foundation & USA & Yes & Yes & - & $102,256.2$ \\
\hline & Hewlett-Packard Company Foundation & USA & - & Estim. & IRS & $9,280.9$ \\
\hline & Howard G. Buffett Foundation & USA & - & Estim. & IRS & $312,162.3$ \\
\hline & John D. and Catherine T. MacArthur Foundation & USA & Yes & Yes & - & $116,411.7$ \\
\hline & Johnson \& Johnson Family of Companies Contribution Fund & USA & - & Estim. & IRS & $54,633.4$ \\
\hline & JPMorgan Chase Foundation & USA & - & Estim. & IRS & $29,175.6$ \\
\hline & Kresge Foundation & USA & - & Estim. & Web & $5,298.8$ \\
\hline & Lemelson Foundation & USA & - & Estim. & Web & $9,933.7$ \\
\hline
\end{tabular}




\begin{tabular}{|c|c|c|c|c|c|c|}
\hline 오 & Name of private provider & $\begin{array}{c}\text { Main } \\
\text { office } \\
\text { location* }\end{array}$ & 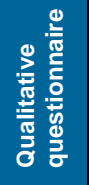 & 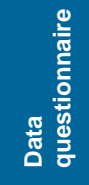 & 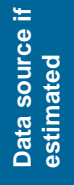 & $\begin{array}{l}\text { Total giving, } \\
2013-2015 \text {, } \\
\text { USD ' } 000\end{array}$ \\
\hline & Leona M. and Harry B. Helmsley Charitable Trust & USA & - & Estim. & Web & $70,633.4$ \\
\hline & Lundin Foundation & Canada & - & Estim. & AR & $24,772.1$ \\
\hline & MasterCard Foundation & Canada & - & Estim. & IRS & $533,031.8$ \\
\hline & Margaret A. Cargill Foundation & USA & Yes & Yes & - & $145,337.9$ \\
\hline & Marisla Foundation & USA & - & Estim. & IRS & $25,458.3$ \\
\hline & McKnight Foundation & USA & Yes & Yes & - & $32,328.9$ \\
\hline & Merck Company Foundation & USA & - & Estim. & IRS & $24,994.7$ \\
\hline & Metlife Foundation & USA & Yes & Yes & - & $52,728.5$ \\
\hline & Michael and Susan Dell Foundation & USA & Yes & Yes & - & $69,413.6$ \\
\hline & Mondeléz International Foundation & USA & Yes & Yes & - & $12,599.3$ \\
\hline & NoVo Foundation & USA & - & Estim. & IRS & $96,680.8$ \\
\hline & Omidyar Network & USA & - & Estim. & IATI & $106,507.8$ \\
\hline & Open Society Foundations & USA & Yes & Yes & - & $309,519.8$ \\
\hline & Oprah Winfrey Leadership Academy Foundation & USA & - & Estim. & IRS & $28,168.5$ \\
\hline & PepsiCo Foundation & USA & - & Estim. & IRS & $25,169.9$ \\
\hline & Pfizer Foundation & USA & - & Estim. & IRS & $15,211.4$ \\
\hline & Rockefeller Brothers Fund & USA & Yes & Yes & - & $45,401.2$ \\
\hline & Rockefeller Foundation & USA & Yes & Yes & - & $361,488.9$ \\
\hline & Segal Family Foundation & USA & Yes & Yes & - & $27,076.9$ \\
\hline & Silicon Valley Community Foundation & USA & - & Estim. & IRS & $95,599.3$ \\
\hline & Skoll Foundation, Skoll Global Threats Fund & USA & - & Estim. & IRS & $38,167.8$ \\
\hline & Susan Thompson Buffett Foundation & USA & - & Estim. & IRS & $724,576.3$ \\
\hline & UPS Foundation & USA & - & Estim. & IRS & $30,127.0$ \\
\hline & W. K. Kellogg Foundation & USA & - & Estim. & Web & $80,690.2$ \\
\hline & Walmart/Walmart Foundation & USA & Yes & Yes & - & $29,689.7$ \\
\hline & Walton Family Foundation & USA & - & Estim. & IRS & $77,580.2$ \\
\hline & Weberg Trust & USA & - & Estim. & IRS & $12,162.3$ \\
\hline & William and Flora Hewlett Foundation & USA & - & Estim. & IATI & $321,535.0$ \\
\hline & Zakat Foundation & USA & Yes & Yes & - & $15,975.8$ \\
\hline & \multicolumn{5}{|l|}{ North American countries, total } & $18,169,311.6$ \\
\hline \multirow{14}{*}{ 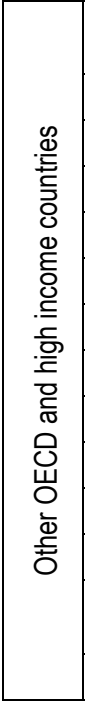 } & $\begin{array}{l}\text { Ahmed Bin Zayed Al Nahyan Charitable and Humanitarian } \\
\text { Foundation }\end{array}$ & UAE & - & Yes & CRS & $3,403.2$ \\
\hline & Al Rahma Charity Association & UAE & - & Yes & CRS & $5,019.3$ \\
\hline & Carlos Slim Foundation & Mexico & Yes & Yes & - & $366,172.4$ \\
\hline & Dar Al Ber Society & UAE & - & Yes & CRS & $35,036.9$ \\
\hline & Dubai Cares & UAE & Yes & Yes & - & $13,485.8$ \\
\hline & Dubai Charity Association & UAE & - & Yes & CRS & $5,279.6$ \\
\hline & Emirates Red Crescent & UAE & - & Yes & CRS & $251,435.1$ \\
\hline & International Humanitarian City of Dubai & UAE & - & Yes & CRS & $8,896.3$ \\
\hline & Nippon Foundation & Japan & Yes & Yes & - & $37,576.3$ \\
\hline & Noor Dubai Foundation & UAE & - & Yes & CRS & $1,400.0$ \\
\hline & Sharjah Charity Association & UAE & - & Yes & CRS & $19,521.1$ \\
\hline & Sharjah Charity House & UAE & - & Yes & CRS & $3,801.0$ \\
\hline & $\begin{array}{l}\text { Sultan Bin Khalifa Bin Zayed Al Nahyan Humanitarian and Scientific } \\
\text { Foundation }\end{array}$ & UAE & - & Yes & CRS & 341.7 \\
\hline & The Big Heart Foundation & UAE & - & Yes & CRS & $4,400.5$ \\
\hline
\end{tabular}




\begin{tabular}{|c|c|c|c|c|c|c|c|}
\hline 을 & \multicolumn{2}{|c|}{ Name of private provider } & $\begin{array}{c}\text { Main } \\
\text { office } \\
\text { location* }\end{array}$ & 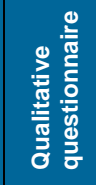 & 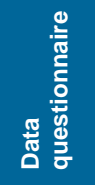 & 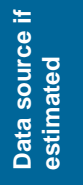 & $\begin{array}{l}\text { Total giving, } \\
\text { 2013-2015, } \\
\text { USD '000 }\end{array}$ \\
\hline & \multicolumn{2}{|l|}{ Toyota Foundation } & Japan & Yes & Yes & - & $3,043.8$ \\
\hline & \multicolumn{2}{|c|}{ Other UAE private philanthropies } & UAE & - & Yes & CRS & $102,582.8$ \\
\hline & \multicolumn{6}{|c|}{ Other OECD and high income countries, total } & $861,395.7$ \\
\hline \multirow{17}{*}{ 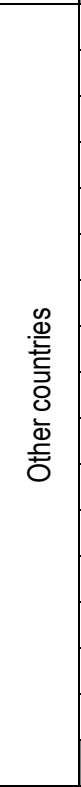 } & \multicolumn{2}{|c|}{ Avina Foundation (Panama) } & Panama & Yes & Yes & - & $10,998.2$ \\
\hline & \multicolumn{2}{|c|}{ Ayrton Senna Institute } & Brazil & Yes & Yes & - & $23,578.1$ \\
\hline & \multicolumn{2}{|c|}{ Azim Premji Foundation } & India & Yes & - & - & - \\
\hline & \multicolumn{2}{|l|}{ Bharti Foundation } & India & Yes & Yes & - & $26,352.3$ \\
\hline & \multicolumn{2}{|c|}{ Chengmei Charity Foundation } & PRC & Yes & Yes & - & $4,014.1$ \\
\hline & \multicolumn{2}{|l|}{ Dunhe Foundation } & PRC & Yes & - & - & - \\
\hline & \multicolumn{2}{|c|}{ Huamin Charity Foundation } & PRC & Yes & Yes & - & $12,140.8$ \\
\hline & \multicolumn{2}{|c|}{ Itaú Social Foundation } & Brazil & Yes & Yes & - & $64,453.8$ \\
\hline & \multicolumn{2}{|c|}{ K. C. Mahindra Education Trust } & India & Yes & Yes & - & $20,781.5$ \\
\hline & \multicolumn{2}{|c|}{ Kenya Community Development Foundation } & Kenya & Yes & Yes & - & $3,369.9$ \\
\hline & \multicolumn{2}{|c|}{ Li Ka Shing Foundation } & $\mathrm{PRC}, \mathrm{HK}$ & - & Estim. & Web & $192,614.3$ \\
\hline & \multicolumn{2}{|c|}{ Nelson Mandela Children's Fund } & RSA & Yes & Yes & - & $4,194.9$ \\
\hline & \multicolumn{2}{|c|}{ Sawiris Foundation for Social Development } & Egypt & Yes & Yes & - & $31,172.9$ \\
\hline & \multicolumn{2}{|l|}{ Tata Trusts } & India & Yes & Yes & - & $303,480.0$ \\
\hline & \multicolumn{2}{|c|}{ Tony Elumelu Foundation } & Nigeria & Yes & Yes & - & $10,000.0$ \\
\hline & \multicolumn{2}{|c|}{ Wildlife Conservation Trust } & India & Yes & Yes & - & $4,212.7$ \\
\hline & \multicolumn{6}{|c|}{ Other countries, total } & $711,363.6$ \\
\hline \multicolumn{3}{|c|}{ GRAND TOTAL } & & & & & $23,868,139.9$ \\
\hline & $\begin{array}{l}\text { * USA } \\
\text { UK } \\
\text { UAE } \\
\text { NLD } \\
\text { PRC } \\
\text { PRC, HK } \\
\text { SUI } \\
\text { RSA }\end{array}$ & $\begin{array}{l}\text { United States of America } \\
\text { United Kingdom } \\
\text { United Arab Emirates } \\
\text { Netherlands } \\
\text { Peoples' Republic of China } \\
\text { Peoples' Republic of China, Hong Kong } \\
\text { Switzerland } \\
\text { South Africa }\end{array}$ & $\begin{array}{r}\text { Estim. } \\
\text { AR } \\
\text { CRS } \\
\text { IATI } \\
\text { IRS } \\
\text { Web }\end{array}$ & $\begin{array}{l}\text { Estimate } \\
\text { Annual r } \\
\text { OECD-D } \\
\text { Internatic } \\
\text { US Interr } \\
\text { Foundati }\end{array}$ & $\begin{array}{l}\text { based on } \\
\text { ort } \\
\text { C Credito } \\
\text { lal Aid Tra } \\
\text { Revenu } \\
\text { 's own w }\end{array}$ & $\begin{array}{l}\text { Reportin } \\
\text { sparency } \\
\text { System } \\
\text { site }\end{array}$ & $\begin{array}{l}\text { ystem } \\
\text { itiative } \\
0-P F)\end{array}$ \\
\hline
\end{tabular}




\section{ANNEX 2: GIVING BY RECIPIENT AND MAIN SECTOR CATEGORY}

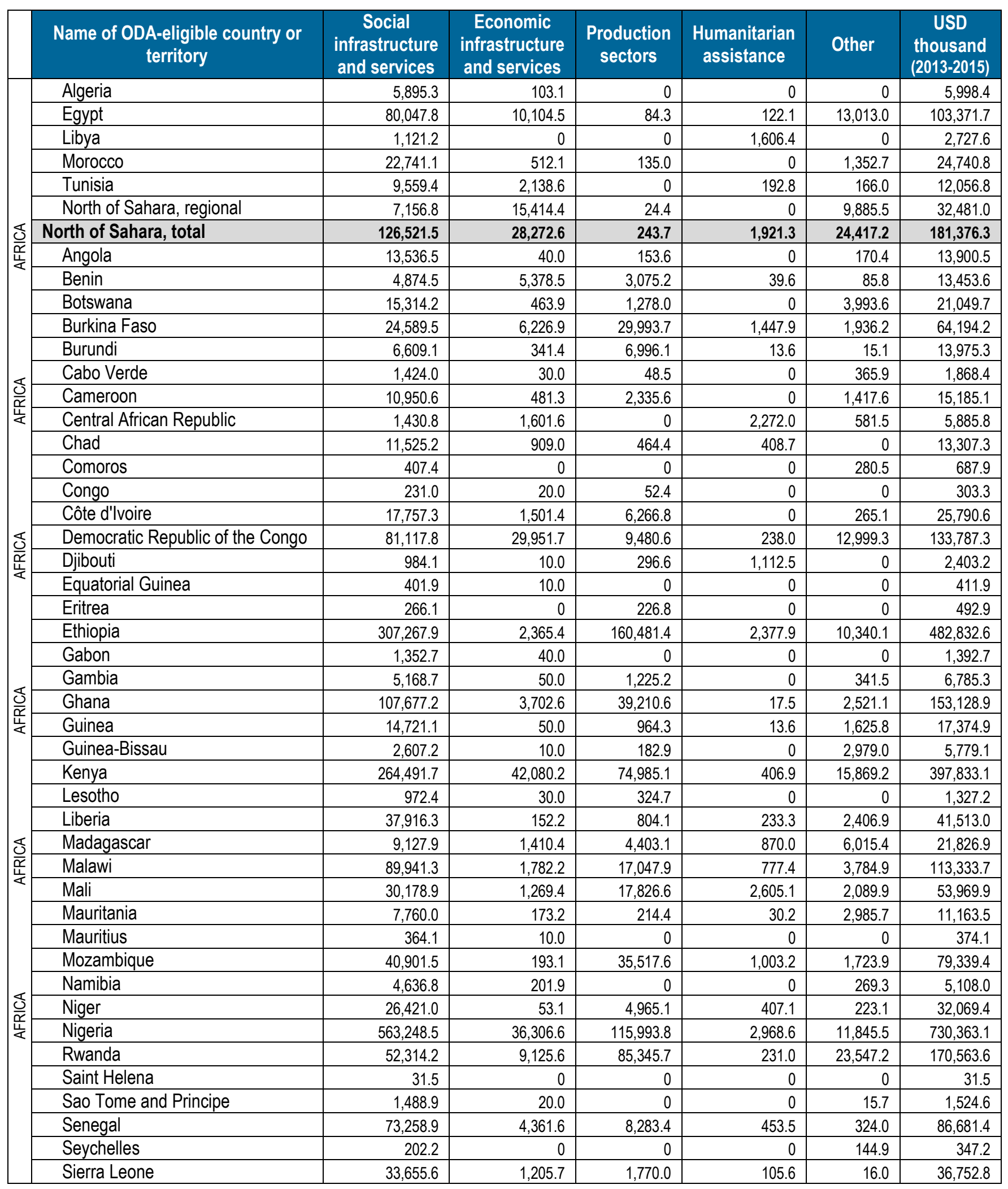




\begin{tabular}{|c|c|c|c|c|c|c|c|}
\hline & $\begin{array}{c}\text { Name of ODA-eligible country or } \\
\text { territory }\end{array}$ & $\begin{array}{c}\text { Social } \\
\text { infrastructure } \\
\text { and services }\end{array}$ & $\begin{array}{l}\text { Economic } \\
\text { infrastructure } \\
\text { and services }\end{array}$ & $\begin{array}{l}\text { Production } \\
\text { sectors }\end{array}$ & $\begin{array}{l}\text { Humanitarian } \\
\text { assistance }\end{array}$ & Other & $\begin{array}{c}\text { USD } \\
\text { thousand } \\
(2013-2015)\end{array}$ \\
\hline & Somalia & $16,240.5$ & 20.0 & 87.4 & $6,049.1$ & 346.9 & $22,743.9$ \\
\hline & South Africa & $378,277.7$ & $12,671.9$ & $3,617.4$ & 2.7 & $22,059.0$ & $416,628.7$ \\
\hline & South Sudan & $20,307.5$ & 10.0 & 914.4 & $3,018.8$ & 904.6 & $25,155.2$ \\
\hline & Sudan & $21,174.5$ & $3,353.7$ & $1,564.0$ & $2,101.6$ & 518.0 & $28,711.9$ \\
\hline & Swaziland & $19,194.6$ & 636.5 & 0 & 0 & 0 & $19,831.0$ \\
\hline & Tanzania & $115,993.9$ & $38,136.0$ & $148,178.7$ & 380.2 & $19,283.8$ & $321,972.5$ \\
\hline & Togo & $8,618.0$ & 585.6 & 205.6 & 62.4 & 0 & $9,471.6$ \\
\hline & Uganda & $162,834.8$ & $29,974.4$ & $86,644.9$ & 92.0 & $3,550.4$ & $283,096.4$ \\
\hline & Zambia & $93,832.5$ & $3,361.9$ & $15,706.0$ & 0 & $1,219.1$ & $114,119.5$ \\
\hline & Zimbabwe & $50,293.5$ & 166.9 & $3,279.9$ & 0 & $1,684.3$ & $55,424.6$ \\
\hline & South of Sahara, regional & $929,757.4$ & $133,673.0$ & $345,097.9$ & $5,615.0$ & $77,401.5$ & $1,491,544.9$ \\
\hline & South of Sahara, total & $3,683,651.0$ & $374,148.7$ & $1,235,510.2$ & $35,355.1$ & $238,147.7$ & $5,566,812.8$ \\
\hline & Africa, regional & $691,875.4$ & $37,767.8$ & $99,907.7$ & $2,044.2$ & $48,038.7$ & $879,633.8$ \\
\hline & AFRICA, total & $818,397.0$ & $66,040.4$ & $100,151.4$ & $3,965.5$ & $72,455.8$ & $6,627,822.9$ \\
\hline \multirow{14}{*}{ 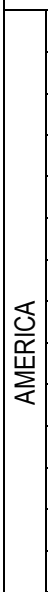 } & Antigua and Barbuda & 7.6 & 0 & 0 & 0 & 0 & 7.6 \\
\hline & Belize & $1,661.8$ & 5.0 & $1,254.0$ & 353.4 & $5,117.2$ & $8,391.5$ \\
\hline & Costa Rica & $3,795.9$ & 270.2 & 0 & 482.4 & $6,815.3$ & $11,363.7$ \\
\hline & Cuba & $17,977.8$ & 27.7 & 245.0 & 0 & $2,556.7$ & $20,807.2$ \\
\hline & Dominica & 135.0 & 0 & 0 & 0 & 0 & 135.0 \\
\hline & Dominican Republic & $1,743.8$ & 517.2 & 883.0 & 0 & 9.0 & $3,152.9$ \\
\hline & El Salvador & $15,685.6$ & 918.3 & $20,520.7$ & $1,212.9$ & 314.2 & $38,651.7$ \\
\hline & Grenada & 46.7 & 0 & 0 & 0 & 0 & 46.7 \\
\hline & Guatemala & $20,242.1$ & 717.2 & $1,835.4$ & $1,542.5$ & $1,090.0$ & $25,427.2$ \\
\hline & Haiti & $65,797.5$ & 837.3 & $8,541.3$ & 578.3 & $3,689.0$ & $79,443.4$ \\
\hline & Honduras & $12,320.6$ & 598.8 & 58.4 & 678.8 & 595.1 & $14,251.7$ \\
\hline & Jamaica & $6,469.7$ & $1,030.2$ & 0 & 0 & 65.0 & $7,564.9$ \\
\hline & Mexico & $449,880.6$ & $10,557.1$ & $31,438.3$ & $3,150.5$ & $101,302.2$ & $596,328.7$ \\
\hline & Montserrat & 7.6 & 0 & 0 & 0 & 0 & 7.6 \\
\hline \multirow{7}{*}{$\frac{\frac{c}{0}}{\frac{w}{w}}$} & Nicaragua & $15,081.7$ & 599.0 & $2,064.8$ & 759.4 & 559.3 & $19,064.2$ \\
\hline & Panama & $6,962.4$ & 325.2 & 125.0 & 255.5 & $1,215.0$ & $8,883.0$ \\
\hline & Saint Lucia & 409.4 & 0 & 0 & 0 & 0 & 409.4 \\
\hline & Saint Vincent and the Grenadines & 13.5 & 0 & 0 & 0 & 0 & 13.5 \\
\hline & West Indies, regional & 573.0 & 142.0 & 0 & 0 & $1,414.0$ & $2,129.0$ \\
\hline & North \& Central America, regional & $68,899.4$ & 993.4 & $2,265.5$ & $13,353.8$ & $17,107.6$ & $102,619.7$ \\
\hline & North \& Central America, total & $687,711.8$ & $17,538.5$ & $69,231.3$ & $22,367.5$ & $141,849.5$ & $938,698.6$ \\
\hline \multirow{7}{*}{ 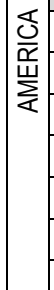 } & Argentina & $22,928.6$ & $1,372.4$ & $1,277.3$ & 21.0 & 774.2 & $26,373.5$ \\
\hline & Bolivia & $4,061.2$ & 199.2 & $7,429.4$ & 14.7 & $3,431.9$ & $15,136.5$ \\
\hline & Brazil & $221,445.6$ & $16,548.2$ & $8,519.1$ & 193.7 & $82,446.1$ & $329,152.7$ \\
\hline & Chile & $21,526.0$ & $4,961.5$ & 190.2 & 319.8 & $13,371.2$ & $40,368.7$ \\
\hline & Colombia & $80,462.7$ & $12,881.3$ & $1,169.3$ & 83.5 & $8,845.0$ & $103,441.8$ \\
\hline & Ecuador & $14,506.8$ & 662.7 & $4,996.4$ & 0 & $6,307.4$ & $26,473.3$ \\
\hline & Guyana & 483.6 & 0 & 0 & 0 & 0 & 483.6 \\
\hline \multirow{9}{*}{ 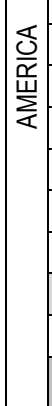 } & Paraguay & $1,858.3$ & 187.0 & 22.4 & 0 & 134.3 & $2,202.0$ \\
\hline & Peru & $50,649.2$ & $4,375.4$ & $6,786.2$ & 0 & $26,382.0$ & $88,192.7$ \\
\hline & Suriname & 578.2 & 271.6 & 170.0 & 0 & $3,194.4$ & $4,214.3$ \\
\hline & Uruguay & $9,825.6$ & 197.3 & 0 & 0 & 73.1 & $10,096.0$ \\
\hline & Venezuela & $22,131.9$ & 870.0 & 171.2 & 0 & 626.4 & $23,799.5$ \\
\hline & South America, regional & $47,700.8$ & 603.1 & $1,817.6$ & $3,800.0$ & $28,426.9$ & $82,348.5$ \\
\hline & South America, total & $498,158.5$ & $43,129.8$ & $32,549.1$ & $4,432.8$ & $174,012.9$ & $752,283.1$ \\
\hline & America, regional & $98,620.1$ & $21,609.0$ & $3,314.2$ & $2,635.4$ & $17,890.6$ & $144,069.3$ \\
\hline & AMERICA, total & $1,284,490.4$ & $82,277.3$ & $105,094.6$ & $29,435.7$ & $333,753.0$ & $1,835,051.0$ \\
\hline
\end{tabular}

PRIVATE FOUNDATIONS' GIVING FOR DEVELOPMENT IN 2013-15

Ongoing efforts to better reflect private philanthropic giving in OECD-DAC statistics on development finance 


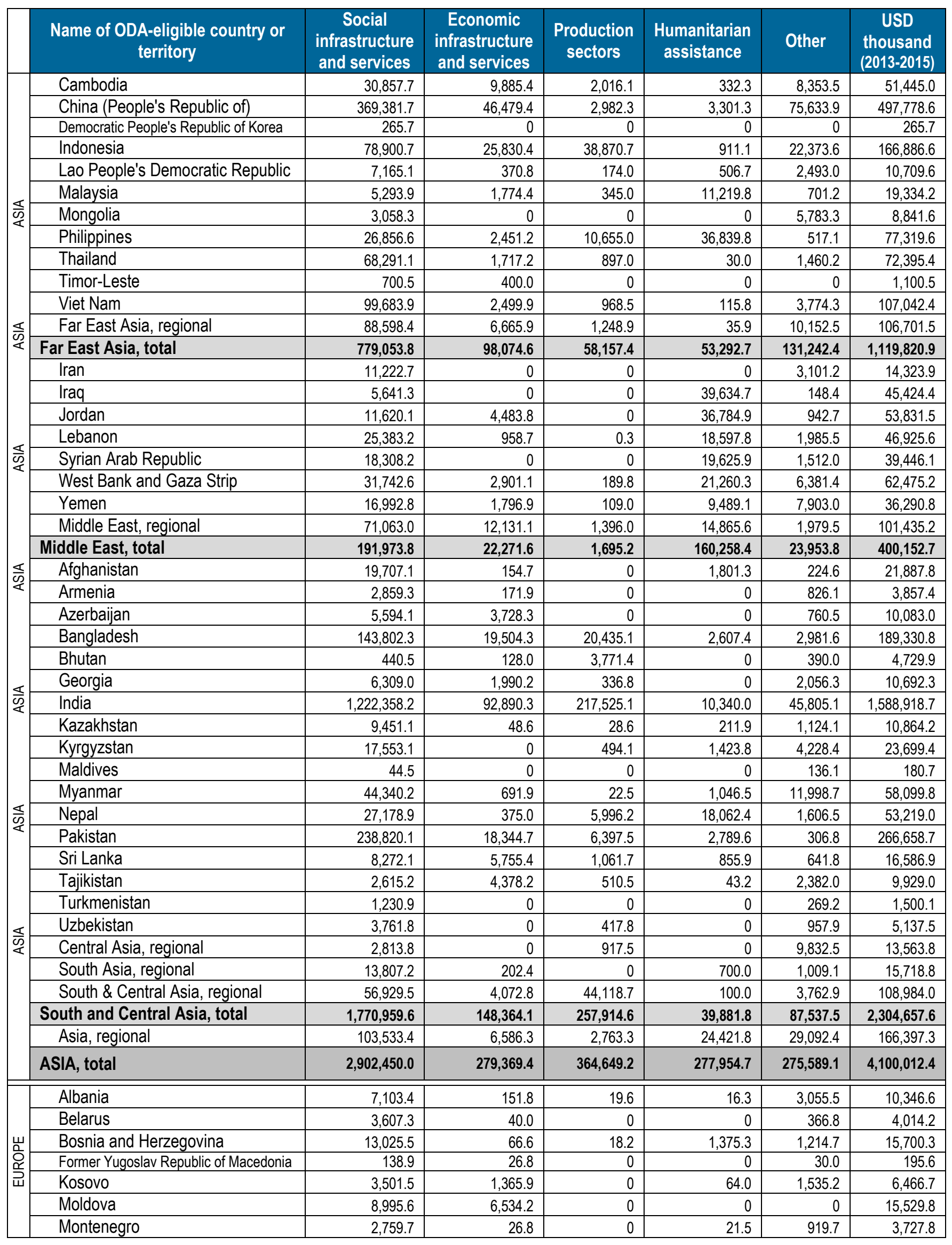




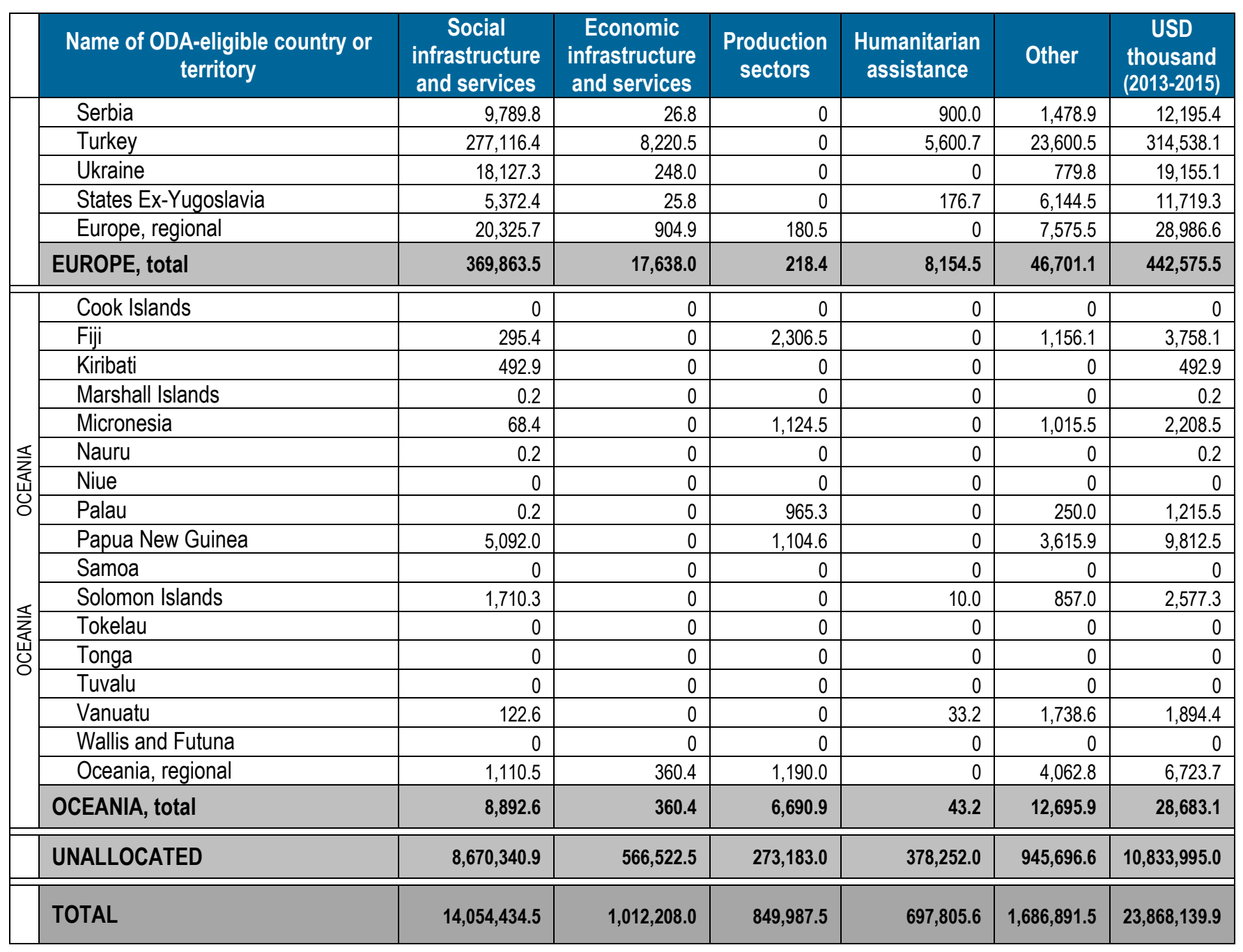


ANNEX 3: DATA QUESTIONNAIRE

\begin{tabular}{|c|c|c|c|}
\hline & Item name & \multicolumn{2}{|c|}{ Description } \\
\hline 1 & Year & \multicolumn{2}{|l|}{$2013,2014,2015$} \\
\hline 2 & Amount (in thousand) & \multicolumn{2}{|l|}{ Any } \\
\hline 3 & Currency & \multicolumn{2}{|l|}{ Any } \\
\hline 4 & Beneficiary country & \multicolumn{2}{|c|}{$\begin{array}{l}\text { Countries and territories on the DAC List of ODA Recipients } \\
\text { www.oecd.org/dac/stats/daclist.htm }\end{array}$} \\
\hline 5 & Project title & \multicolumn{2}{|c|}{ Channelling organisation or other } \\
\hline 6 & Project description & \multicolumn{2}{|c|}{ Descriptive information } \\
\hline 7 & \multirow{2}{*}{ Sector and subsector } & \multirow{2}{*}{\multicolumn{2}{|c|}{$\begin{array}{l}\text { DAC sectoral classification } \\
\text { www.oecd.org/dac/stats/purposecodessectorclassification.htm }\end{array}$}} \\
\hline 8 & & & \\
\hline 9 & Alternative sector category & \multicolumn{2}{|c|}{ Alternative sector classification, if applicable } \\
\hline 10 & Financial instrument & \multicolumn{2}{|c|}{ Grant, loan, equity, shares in collective investment vehicles, other } \\
\hline 11 & Modality of giving & \multicolumn{2}{|c|}{$\begin{array}{l}\text { Core support, earmarked support and project-type interventions, charitable investment, } \\
\text { direct giving: scholarships/fellowships/training and own execution }\end{array}$} \\
\hline $\begin{array}{c}12 \\
- \\
28\end{array}$ & SDG $1-S D G 17$ & A range $0-100 \%$ & $\begin{array}{l}\text { Collection of this information was } \\
\text { abandoned during the survey process } \\
\text { due to limited availability of this } \\
\text { information. }\end{array}$ \\
\hline 29 & Climate change: mitigation & \multirow{2}{*}{ Using DAC Rio Markers } & \multirow{2}{*}{ Merged due to limited data availability. } \\
\hline 30 & Climate change: adaptation & & \\
\hline 31 & $\begin{array}{l}\text { Additional information (free } \\
\text { text, hyperlinks) }\end{array}$ & \multicolumn{2}{|l|}{ Any } \\
\hline
\end{tabular}

Furthermore, based on information provided in the descriptive fields, the following category was created:

\begin{tabular}{|l|l|l|}
\hline \multicolumn{1}{|c|}{ Item name } & \multicolumn{1}{c|}{ Kind of information generated } \\
\hline Channel of delivery & $\begin{array}{l}\text { Name of institution channelling the funds, departing from the DAC List of ODA-eligible } \\
\text { international organisations; www.oecd.org/dac/stats/annex2.htm }\end{array}$ \\
\hline
\end{tabular}




\section{ANNEX 4: ESTIMATION OF FOUNDATIONS' CONTRIBUTION TO THE SDGS}

For the purpose of this working paper, a simplified approach was used to estimate foundations' contribution to the 2030 Agenda: each SDG is assigned a percentage representing the share of the total giving relating to it. The estimation is based on a simple mapping between the DAC purpose codes and SDG targets, complemented with a key word search relevant to the philanthropic sector (see table 4 below).

It is important to highlight that this method does not prevent against overlap and double counting among individual SDGs, as a single activity may be considered contributing to multiple SDGs (i.e. percentages should not be added up). Neither can it guarantee that all activities administered with the intention of supporting certain SDGs have been included in the respective SDG sums. It may also overestimate financiers' contribution to specific SDGs with a typically horizontal and cross-cutting nature, such as SDG 9 and SDG 10.

Since no yet agreed mapping exists between the DAC statistical standards and the SDGs, the estimates presented should be considered as roughly indicative. The mapping developed for this survey however benefitted from the most recent discussions on this topic in the context of the DAC Working Party on Development Finance Statistics (WP-STAT). ${ }^{\text {xiii }}$

Table 4. Simple mapping between the collected data and SDGs

\begin{tabular}{|c|c|c|c|c|c|}
\hline \multirow{2}{*}{ @ } & \multirow{2}{*}{$\begin{array}{l}\text { DAC SECTOR/PURPOSE } \\
\text { CODE }\end{array}$} & \multirow{2}{*}{$\begin{array}{c}\text { KEY WORDS } \\
\text { (used in columns "Project title" and "Project description") }\end{array}$} & \multirow{2}{*}{ Other } & \multicolumn{2}{|c|}{$\%$ of total } \\
\hline & & & & ALL & $\begin{array}{l}\text { excl. } \\
\text { BMGF }\end{array}$ \\
\hline 1 & 16010, 43040, 720xx, 730xx, 740xx, & poverty, poor, land right, ownership, resilien & & 9 & 13 \\
\hline 2 & $\begin{array}{l}311 \times x, 313 x x, 52010,43040 \\
41050,12240,41030,12240\end{array}$ & hunger, food, nutrit, stunt, feed, lactat, vitamin & & 15 & 15 \\
\hline 3 & $\begin{array}{l}12 x x x, 13 x x x, 16064,16050,16063 \\
21020\end{array}$ & $\begin{array}{l}\text { alcohol, tobacco, mental, narcotic, drug, well-being, wellbeing, medic, health, } \\
\text { medic }\end{array}$ & & 55 & 32 \\
\hline 4 & $11 x x x, x x x 81$ & training, education, teaching, teacher, learn, scholar, formation, school & & 16 & 26 \\
\hline 5 & $\begin{array}{l}\text { 13010, 13020, 13030, 13081, } \\
\text { 15170, 15180, }\end{array}$ & woman, women, girl, sexual, gender, female, lgbt, fgm, femme, fille, & & 16 & 18 \\
\hline 6 & $14 \mathrm{xxx}$ & $\begin{array}{l}\text { hygien, freshwater, fresh water, watershed, water scar, wastewater, wetland, } \\
\text { drinking water, river, sanitat }\end{array}$ & & 3 & 3 \\
\hline 7 & $23 x \times x$ & renewable, fossil, energ, solar, photovolt, electri, cookstove, cook stove & & 1 & 2 \\
\hline 8 & $\begin{array}{l}11330,15261,16020,240 x x, 250 x x \\
331 x x, 332 x x, x x x 81\end{array}$ & econom, job, labour, labor, decent work, slavery, entrepr, enterpr & & 11 & 15 \\
\hline 9 & $\begin{array}{l}210 x x, 220 x x, 240 x x, 25025,321 x x \\
x x x 82\end{array}$ & industr, technolog, innovat, sme & & 15 & 18 \\
\hline 10 & $15160,15170,16010$ & $\begin{array}{l}\text { inclusi, income, marginali, minorit, discriminat, disadvantag, religio, ethnic, } \\
\text { equal, migrant }\end{array}$ & & 17 & 15 \\
\hline 11 & $\begin{array}{l}16030,16040,41040,41050 \\
43030,43040\end{array}$ & $\begin{array}{l}\text { house, housing, slum, urban, settlement, municipal, heritage, village, city, } \\
\text { cities, rural, air qualit, air pollut, } 100 \text { resil, sustainable cit }\end{array}$ & & 11 & 13 \\
\hline 12 & $14050,31165,31192,31640,33210$ & $\begin{array}{l}\text { sustainab chemical, recycl, reus, re-us, natural reso, palm oil, waste, post- } \\
\text { harvest, fossil, stunt, food los }\end{array}$ & & 5 & 5 \\
\hline 13 & & climat, resilien, adapt & $\begin{array}{l}\text { Climate } \\
\text { marker }\end{array}$ & 7 & 13 \\
\hline 14 & $313 x x, 41020$ & marine, coast, ocean, fish & & 1 & 2 \\
\hline 15 & $\begin{array}{l}31130,312 x x, 41010,41020 \\
41030,41081,41082\end{array}$ & $\begin{array}{l}\text { palm oil, poaching, extinct, desertification, flora, fauna, wildlife, forest, amazon, } \\
\text { biodivers, bio-divers }\end{array}$ & & 5 & 9 \\
\hline 16 & $15 x x x, 22040,31162,43050$ & $\begin{array}{l}\text { justic, judic, corrupt, accountab, civil soc, rule of law, legal, legislati, freedom, } \\
\text { rights, transp, particip, birth regi, media }\end{array}$ & & 10 & 17 \\
\hline 17 & $\begin{array}{l}15114,15119,15123,15127 \\
15142,16062,33120,33130 \\
33140,600 x x\end{array}$ & $\begin{array}{l}\text { ODA, official development assistance, SDG, sustainable development goal, } \\
\text { MDG, millennium development goal, south-south, south south, indebt }\end{array}$ & & 1 & 0 \\
\hline
\end{tabular}

xiii A 2015 OECD-DCD review of purpose codes and policy markers in light of the SDGs and post-2015 Agenda indicated that at the goal level, there was generally a good mapping with purpose codes and markers but at the target level, in many cases the classifications were not detailed enough to capture support for the specific targets. Furthermore, some purpose codes related to more than one target, and vice versa, and in several cases no direct linkage was found. Therefore, the DAC sectoral classification has been undergoing a revision process to add necessary detail to selected sectors and to better align it with the goals and targets. 


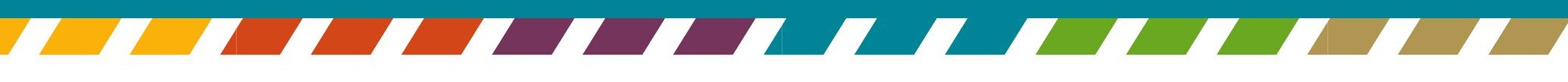

